\title{
AMPEL HERITAGE TOURISM AREA IN THE CONTEXT OF SUSTAINABILITY
}

\author{
Galuh Fajarwati*, Komang Ayu Laksmi Harshinta Sari*, Faniah Shafira Amir \\ Ishak** \\ *)Free Lance Architect, Surabaya Indonesia \\ **)IAI Member, Surabaya Indonesia \\ e-mail: fnhshafira@gmail.com
}

\begin{abstract}
The city of Surabaya grows rapidly affecting the physical urban areas development, especially the tourist area. One of it is Ampel Region that is defined as a region of religious tourism and cultural heritage buildings by the city government as stated in Mayors Regulation Number: 188.45 / 251 / 402.1.104 / 1996. The area has potential for tourism and high economy development, but it does not compliment each other. So, it is necessary to review and analyse Ampel area to find a suggestion to harmonise the trade and economic development in order to continue supporting the function of the area as religious tourism. The methods used in this paper are descriptive approach and the application of sustainable development goals criteria, named four pillars of sustainability. Urban heritage plan will be developed specifically in the area of Ampel Mosque and street vendors (PKL) around it. The basic form of the tourist area has a broad scope, including the regional areas, specifically residential areas that will be affected by the system. However, this can improve the economy and income of the local communities. Reviewing and structuring this region will broaden up Ampel's impact to the life pattern of the people around. The results of this study are several physical elements such as infrastructure (circulation and parking), open space, socio-economic and sustainability improvement by providing solutions in the form of recommendations for the design of sustainability implementation and efforts to help non-physical problems in accordance with the results of the analysis of the Ampel area.
\end{abstract}

Keywords: tourist areas, economic, residential areas, sustainability

\section{INTRODUCTION}

Based on the East Java Provincial Regulation No. 6 of 2017 of Tourism Development Master Plan Year 2017-2032 East Java province, Ampel area is 
designated as the object of religious tourism. Ampel region is a region in the revitalisation area with the historical value. Based on predefined rules, the government has made some revitalisation plans to develop Ampel region such as the development of centres of PKL between two main streets, Jl. Nyamplungan and Jl. Pegirian.

Ampel Village is an area in the North Surabaya region where the majority of the population is Arab, Madura, Java and Chinese ethnics. Current condition of the village is densely populated settlements with terraced houses meet narrow alleys and majority closed waterways. The settlement patterns are natural, with a circular pattern of Sunan Ampel mosque and dining in the centre. Architectural detail is used in every building, which is located in the traditional style of the region growing from the assimilation of Majapahit and Chinese.

Urban heritage in Ampel region is religious tourism centred at Ampel Mosque. Many people, especially people from other regions, come to visit the tomb of Sunan. The eminent activity is praying. There are several other religious activities as well in the Ampel Mosque. Thus, it forms the Ampel Mosque neighbourhood as a very active area. Apart from religious tourism activities in the Ampel Mosque, this region is also a residential, trade, and services area with high mobility. Activities in this area are very densely overlapping, causing congestion and affecting the public comfort.

The analysis of urban settlement, sustainable development goals, the four pillars of sustainable and affordable housing within the four-dimensional sustainability (micro) Ampel village in the region are expected to meet and resolve the issue of economic, social, cultural and tourism in Ampel region. Religious tourism department is responsible to run it smoothly and support the activity to harmonise all aspects of community activities.

The main problem in Ampel region is the lack of awareness among economic activities, culture and neighbourhoods and the lack of facilities to accommodate and support the activities in the environment, particularly in religious tourism context, resulting in some of environmental problems. The consequence is congestion caused by indiscriminate parking, road width reduction due to street vendors who open stall in front of people's homes and so forth.

\section{THEORY / RESEARCH METHODS}

The study of literature includes several studies that serve as reference for comparison. It is divided into several parts. The first is a study related to the implementation of the four pillars of sustainability (Toofa, 2014 and Akadiri et al, 2012), Sustainable Development Goals (Sutopo et al, 2014), Housing and Settlement Sustainability and Housing for Smart Environment (UN Habitat, 2011). The second is a study related to the implementation of urban design, namely the Urban Design Process (Hamid Shirvani, 1985), The Death and Life of Great American Cities (Jane Jacobs, 1961), 10 Principle Placemaking (Tibbalds Francis, 1992). 


\section{Urban theory}

Physical element forming area by Hamid Shirvani (what year):

1. Land use (land use)

2. Building Management (building form and massing)

3. Circulation and parking

4. Outdoor

5. Pedestrian path

6. support activities

7. Signs, billboards, etc.

8. Preservation and conservation

The emphasis is on the use and occupation of space (Kevin lynch 1961). As a space of social interaction and human activities is taken from Jane Jacobs (1961). The emphasis on continuity, the preservation of a sense of place, maintaining ancient buildings and historical relics as a landmark are highlighted by Francis Tibbalds (1992).

\section{Sustainability theory}

Sustainable architecture is an architecture that meets current needs without endangering the lives of future generations to meet their own needs. This statement covers the entire cycle of a building or so-called life cycle built starting from the development, utilisation, maintenance and demolition of buildings.

\section{Key principles of Sustainability}

Four main principles of sustainable concepts that need to be considered are 1) Economic sustainability, 2) Environment sustainability, 3) Social sustainability and 4) Cultural sustainability. The strategies are grouped by Toofan (2014) and Akadiri et al (2012) as follows:

1. Economic Growth
a. Tourist
b. agricultural
c. Industrial design

2. Worthy Environment
a. Preservation of natural condition
b. Planning urban design
c. Design for human comfort
d. Period before waking up
e. Development process
f. Post-habitation

3. Respect to People

a. Creating a healthy environment

b. Create a comfortable environment (create a comfortable pedestrian, transport, accommodation facilities for people with disabilities)

4. Culture
a. Cultural aspects that are around the area 


\section{Sustainable Development Goal}

Sustainable Development Goals (SDG) is a set of programs and development targets for and by all UN member states, including Indonesia. SDG is valid from 2016 to 2030. SDG replaces the Millennium Development Goals (MDG), which ended in 2015. JITET Indonesia as one of the signatory country to the Sustainable Development Goals, or the Sustainable Development Goals (SDG) is socially and morally bound to implement it. Indonesia is not expected to be late in its implementation. However, SDG governance will determine whether Indonesia will be able to meet requirements as follows:

1. Removing All Forms of Poverty

2. Ending Hunger, Achieve Food Security and Nutrition Improvement and Sustainable Agriculture Declares

3. Assuring Healthy Life and Improve Welfare of Residents in All Ages

4. Assuring Quality Fair and Inclusive Education as well as increasing opportunities Lifelong Learning for All

5. Achieving Gender Equality and Empower All women and girls

6. Ensures Availability and Management of Water and Sanitation Sustainable

7. Ensures Access to Affordable Energy, Reliable, Sustainable, and Modern

8. Improving economic growth equitable and sustainable, optimal labor and productive and decent work for all

9. Build a Resilient Infrastructure, Promote Industrialization and Promoting Inclusive and Sustainable Innovation

10.Reducing Inequality Within and Between Countries

11.Making Cities Inclusive and Human Settlements, Secure, resilient, and Sustainable

12.Pattern guarantee Sustainable Production and Consumption

13.Taking Immediate Action to Combat Climate Change and Impacts

14.Preserving the ocean, Navy and Marine Resources sustainably for Sustainable Development

15.Protecting, Restoring and Improving Continuous utilisation of Terrestrial Ecosystems, Managing forests sustainably, Combating Desertification and Land Degradation Stopping and restoring biodiversity and Stop Loss BIOLOGICAL

16.Improve Inclusive Society and Peace for Sustainable development, provide access to justice for all, and Institution Building Effective, accountable and inclusive at All Levels

17.Means of Implementation strengthen and revitalize the Global Partnership for Sustainable Development

\section{Environmental Concerns of Urban Settlement}

Environmental Problems of Urban Settlements can be classified following the classification fix, such as:

1. Natural Environment

2. The built environment

3. Socio-economic, cultural

4. Political Environment

5. Healthy safe and secure environment 
The research method used was qualitative research with data collection, analysis and interpretation (Groat and Wang, 2013). Of the many theories that are used, we conducted an analysis using equalisation of each point theory with the following results (Table 1). 


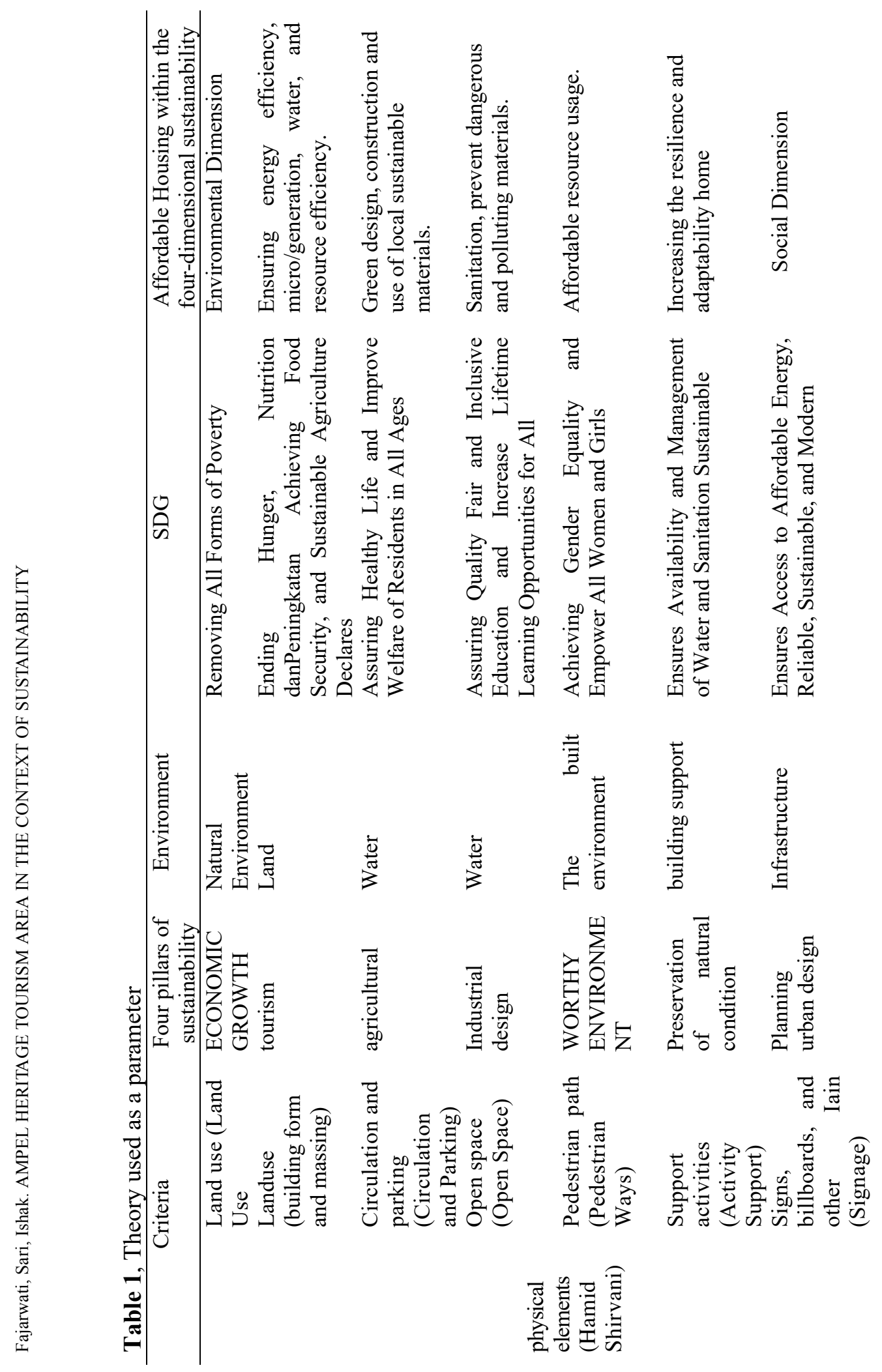




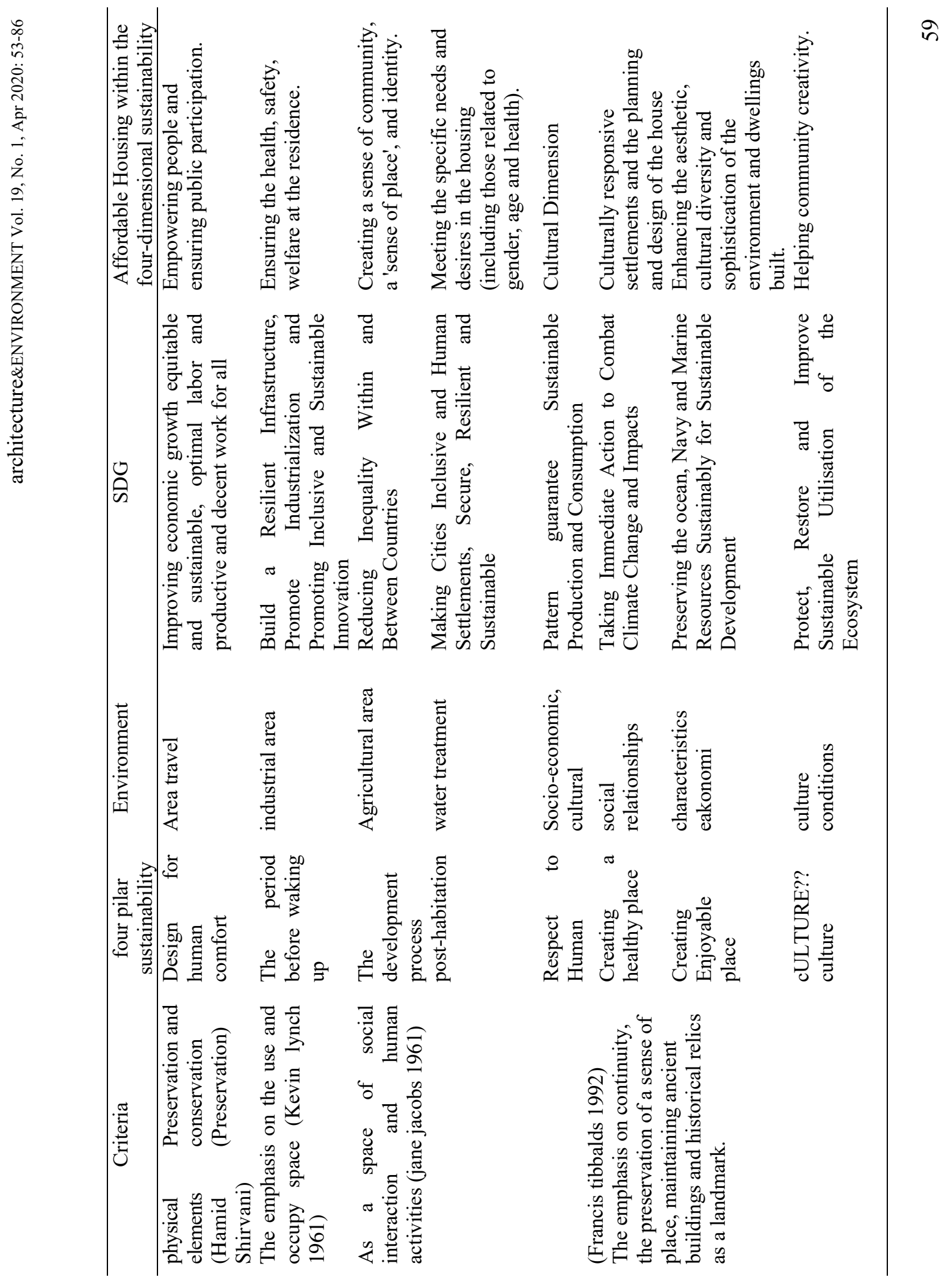




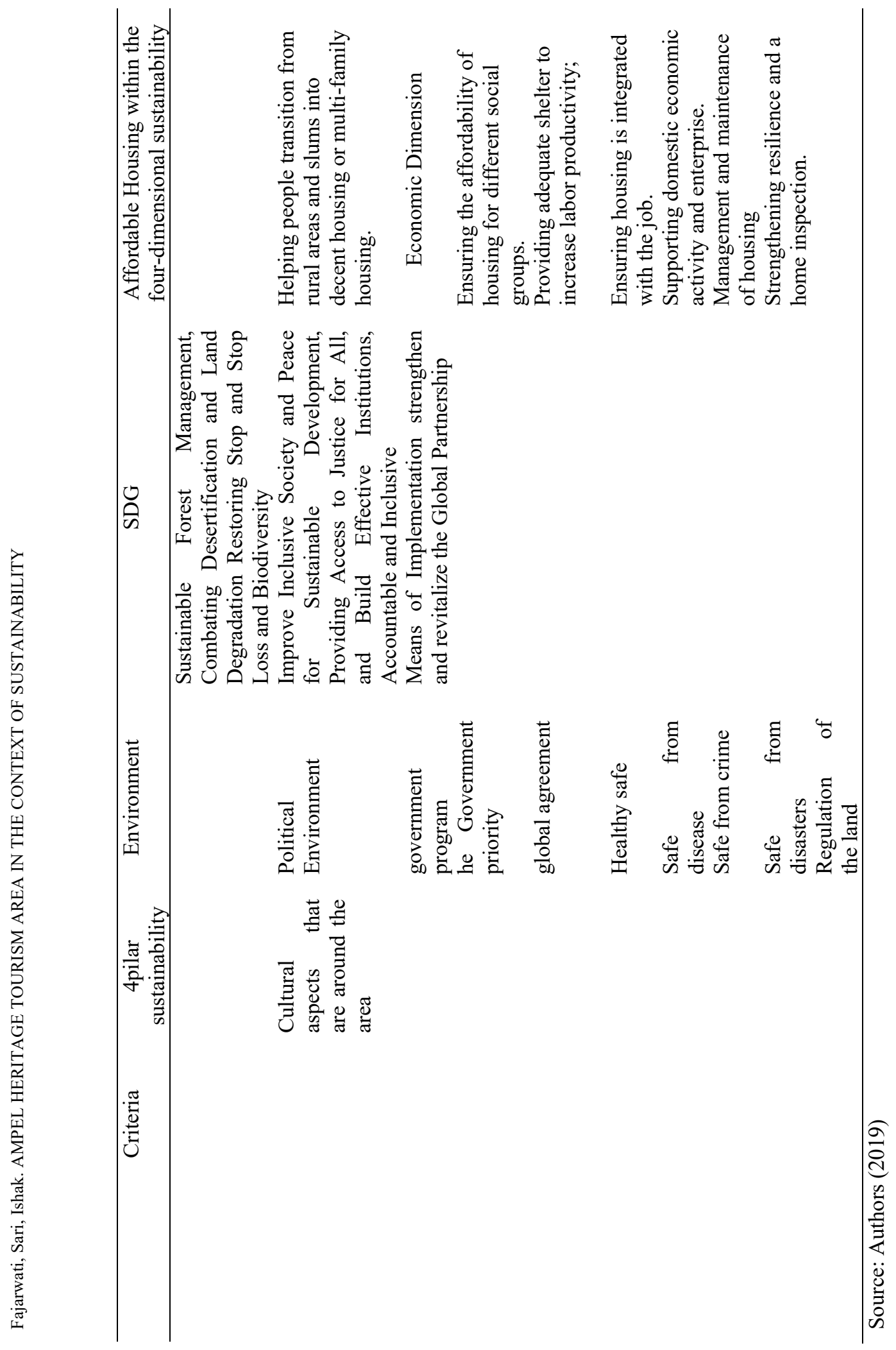


Table 2, Parameters used in for analysis

\begin{tabular}{|c|c|c|}
\hline No. & Analysis & Parameter \\
\hline 1 & $\begin{array}{l}\text { physical } \\
\text { elements }\end{array}$ & $\begin{array}{l}\text { Land use (Land Use) included in political points of environment that } \\
\text { the government program, the government plans, and other related } \\
\text { regulations surrounding territories correspond stats area design. } \\
\text { Land use (Building Form and Massing) including Land regulation in } \\
\text { the development process. } \\
\text { Circulation and parking (Circulation and Parking) included in } \\
\text { sustainable infrastructure and encourage innovation included in it } \\
\text { are pedestrian ways and signage. } \\
\text { Open space (Open Space) with preservation of natural conditions, a } \\
\text { tourist area and or agriculture. } \\
\text { Support activities (Activity Support) emphasis on support facilities } \\
\text { that can empower and accommodate aspiration creativity } \\
\text { surrounding communities and creating a sense of community and } \\
\text { meet the needs of the community. } \\
\text { Preservation and conservation (Preservation) will be placed on } \\
\text { continuity, the preservation of a sense of place, maintaining ancient } \\
\text { buildings and historical relics as a landmark and culturally responsive } \\
\text { settlements, planning and design as well as improving the environment } \\
\text { of cultural sophistication and dwellings in the wake. }\end{array}$ \\
\hline 2 & $\begin{array}{l}\text { Socio- } \\
\text { economic }\end{array}$ & $\begin{array}{l}\text { Providing social interaction space with attention to economic } \\
\text { characteristics, environmental security, environmental maintenance, } \\
\text { settlement inclusive, resilient, and sustainable. } \\
\text { Ensuring a place to stay integrated with the work and support domestic } \\
\text { economic activities/companies. }\end{array}$ \\
\hline 3 & $\begin{array}{l}\text { Sustainabil } \\
\text { ity }\end{array}$ & $\begin{array}{l}\text { Giving priority to user comfort and safety related to sustainability and } \\
\text { water availability, energy efficiency, resource efficiency, the application } \\
\text { of local materials and sanitation. Minimalising the negative impact of } \\
\text { the built environment impacts and prioritise action on climate change } \\
\text { and natural disasters. }\end{array}$ \\
\hline
\end{tabular}

Source: Researcher (2019)

\section{RESULTS AND DISCUSSION}

\section{General data area}

Ampel region is largely residential area at the same trade and religious tourism ambience. Eighty percents of the buildings in the Ampel area is certified buildings and property. The building is a functional building for the building and land use rights. The explanation is illustrated in Figures 1 and 2.
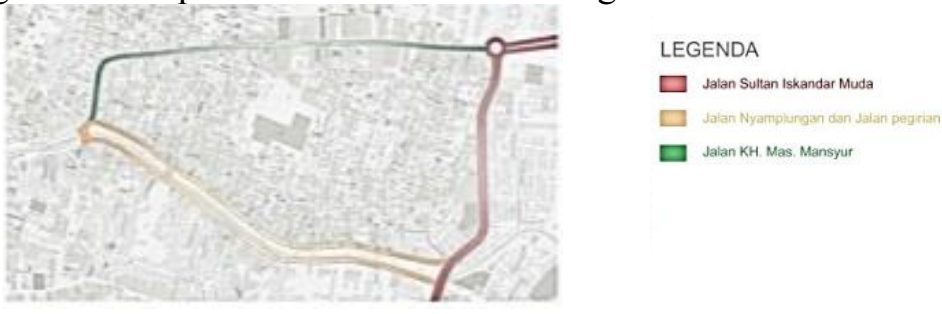

Figure 1.Name roads in the area Ampel

Source: Internet (should be more specific following the rule of image citation) 


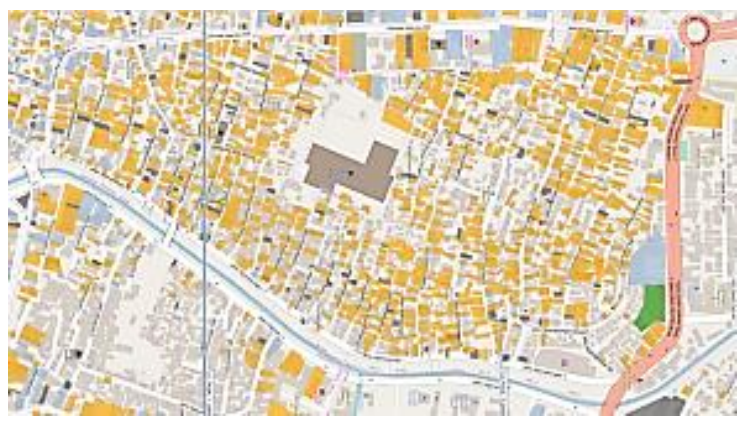

- Yellow: certified

- Gray: property rights

- Dark gray: not certified.

Figure 2 Map of the area parcels Ampel

Source: Internet (should be more specific following the rule of image citation)

\section{Physical elements}

- Land use

Ampel region in PERDA No. 12 of 2014 on Spatial (what??) is designated as a heritage area. However, the existing circumstances depicts that majority of the area is a residential and commercial area. (Figure 3)
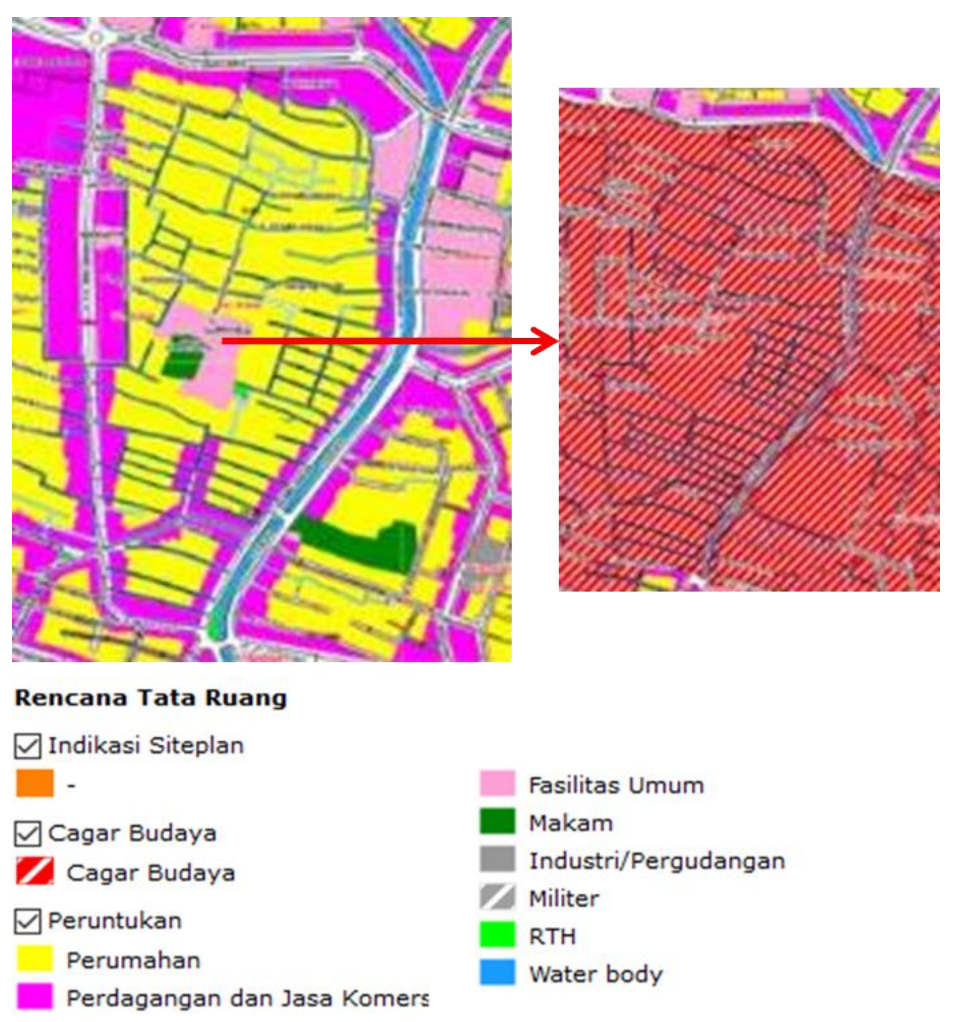

Figure 3 Land use planning.Rencana Ampel region

Source: Internet (should be more specific following the rule of image citation) 
Based on the facts and analysis, the problem of Ampel is the lacking capacity of the area to function for the region. According to the functions of Ampel neighbourhood, regional religious tourism has not run optimally worsen by the rapid growth of population and economy. It highly affects the potential of Ampel as a tourist area. Seeing this phenomenon, should Ampel region in revitalisation by adjusting the diversity of activities and functions of this region so that a functional area can support each other.

- Landuse

Other problems of Kampung Ampel are the use of land or land use. Settlement in the area is pretty solid, hard to find vacant land or green land. The lack of green open space (RTH) causes several problems, such as environmental degradation and unsufficient land as water catchment areas. The building regulations for Ampel area, as stated in Surabaya city government regulation of the mayor of Surabaya No. 75 of 2014 are:

- Basic building coefficient

1. Low-density informal settlements are directed to use the land with a basic building coefficient of $60-80 \%$

2. High-density informal settlements are directed to use the land with a basic coefficient of $80 \%$

3. Regional trade and services are $60 \%$ set to land at the centre. A lot of buildings violate these provisions so that the policy needs to be reconsidered to increase the cost of the agreement.

- The coefficient of building floor

Based on several considerations, the building floor coefficient of Ampel area is set as follows:

1. For commercial buildings, the direction coefficient floor is between 2-4 floors depends on the need and purpose.

2. For other buildings, the building floor coefficient is adapted to the needs and functions of the activities in it. The other building is a residential building that goes round and supporting facilities. The suggested coefficient for this building is between 1-2 floors.

Based on the above factors, the coefficient of building floor area in Ampel area is as follows:

1. Residential buildings with high density and value of the basic building coefficient of $80 \%$ for $1-2$ floor of the building floor coefficient value is 80 $160 \%$

2. Settlements with a low and medium density that has the basic building coefficient value of $60-80 \%$ with the number of floors of the building between the floors $1-2$ of the building floor coefficient value of $60-160 \%$

3. Commercial buildings and services that have value basic building coefficient of $60 \%$ with the number of floors of the building then floor 2-6 of the building floor coefficient value of $120-360 \%$. 
- Building border line

1. For areas that have been regularly awakened and unconditioned permanently but did not qualify GSB, the application of these buildings (what??) does border line sat on these buildings make reforms, rehabilitation or renovation or in special circumstances when done.

2. For woke up less area and unregulated and unconditioned buildings or bad, then the application of the GSB held at the time of renewal or rehabilitation program organized

3. For areas that are still empty, GSB application set as early as possible by using the requirements of the building or included in the IMB

4. For block condition or superblock, GSB application must be adjusted to the height of constructed buildings with the location within the road in front of it.

- Circulation

Circulation is an access to the market, the area of education and health services with the state of the roads in asphalt. For circulation in a residential area, it uses the paving pavement. Tourist can pass several main lines in Ampel religious tourism area where this road is prioritised for pedestrians. Many traders' vendors meet several entrance roads to the holy Ampel Mosque. The state of the roads can be seen in Figure 4.

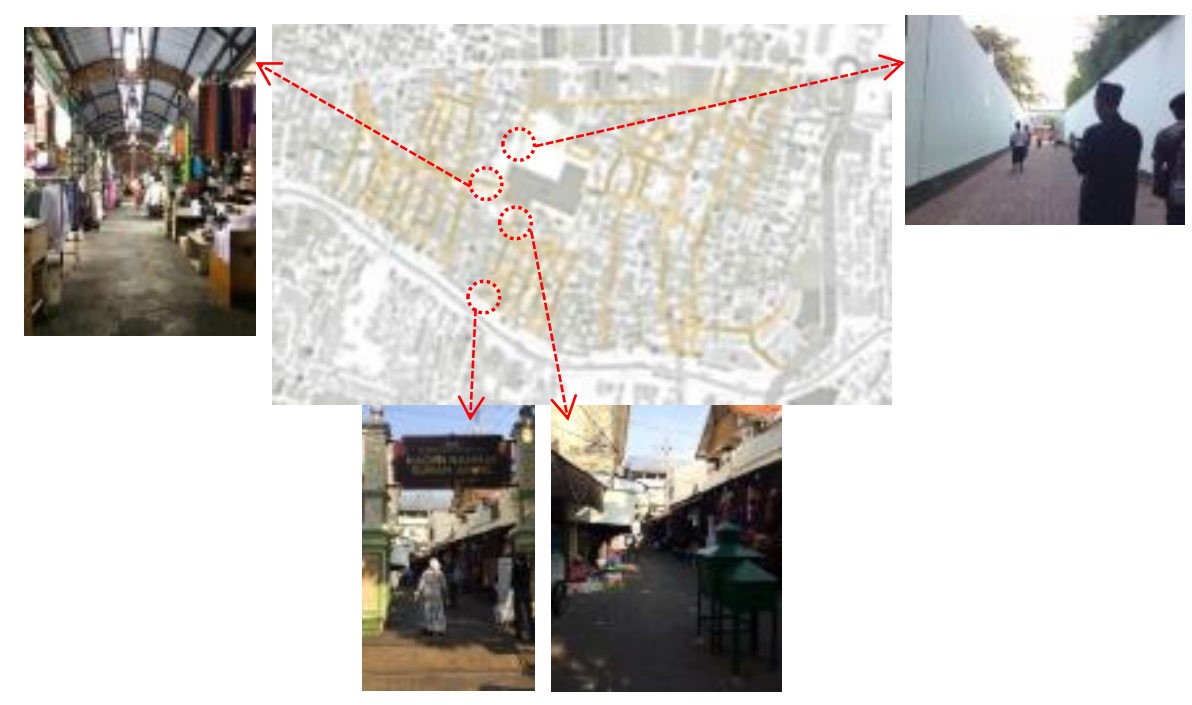

Figure 4. Street Condition of around Masjid Ampel Source: Personal Documentation

Based on the field survey, it was found that some village road conditions is not good enough. Potholes will automatically reduce the comfort of residents when passing the road in the township. The physical condition of the existing road can be described in Figure 5 to 9 as follows: 
1. Jalan Ketapang large
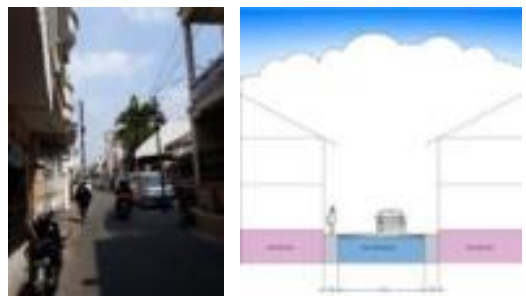

Figure 5 Large chunks of Road Ketapang Source: Personal Documentation

2. Jalan Ampel mosque

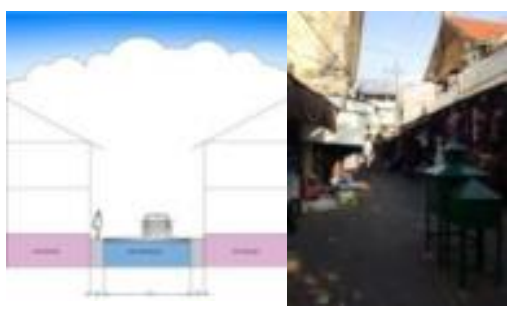

Figure 6. Section of Road Ampel Mosque Source: Personal Documentation

\section{Jalan Ampel Maghfur}
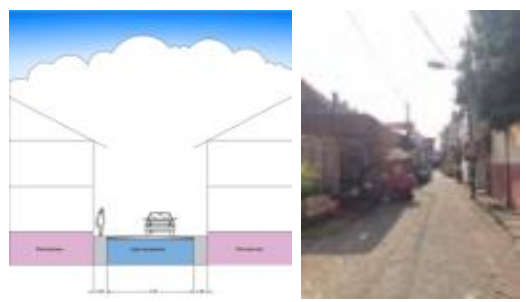

Figure 7. Section of Road Ampel Maghur Source: Personal Documentation

\section{Jalan Gubah Kidul}

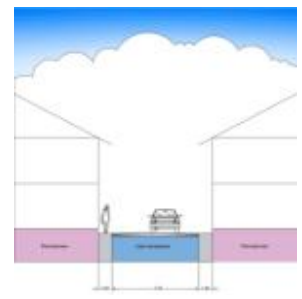

Jalan Ketapang is a big residential area, a large ketapan road has no pedestrian paths and parking is filled by four-wheeled vehicles owned by residents. So it is very difficult for pedestrians to pass directly due to vehicles passing through this road.

Ampel Mosque Road is the main route to the holy Ampel travel. This road is designated for pedestrians. However, along the way it is full of traders Muslim clothing, special food Ampel and books. Therefore, pedestrians must be careful and often hindered by visitors who are shopping.

Jalan Ampel Maghfur is a residential area. There are educational facilities in this way. There are many children and pedestrian going through this road. However, the road Ampel Maghfur does not have a special path for pedestrians. The street is supposed to be on a special note because of the school facilities and children activities.

Jalan Gubah Kidul is a small road between the settlement. It acts as a shortcut out of Ampel. This road has a pavement condition. But it is not good. It needs improvement with consideration of sustainable pavement to facilitate the maintenance and environmental response. 


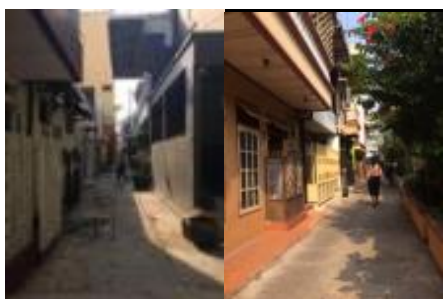

Figure 8 .Potongan road composed Kidul

Source: Personal Documentation

5. Jalan Ampel Gubahan

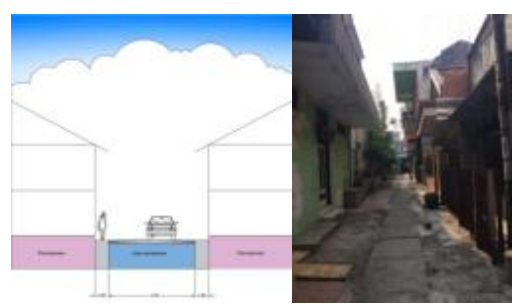

Figure 9. Section of Ampel Gubahan

Source: Personal Documentation
Jalan Ampel Gubahan is a small road between the residents. It has $3 \mathrm{~m}$ wide and only at a designated pedestrian. This road is not good and has many holes. It needs to be emphasised because this region is inhabited by a majority of elderly people. Therefore, it is necessary to facilitate the improvement.

The main roads are Nyamplungan road, street KH Mas Mansyur, Pegirian road, Jalan Sultan Iskandar Muda. Those roads are quite good with good asphalt pavement (Figure 10). Thus, rider feels quite comfortable passing through this road.

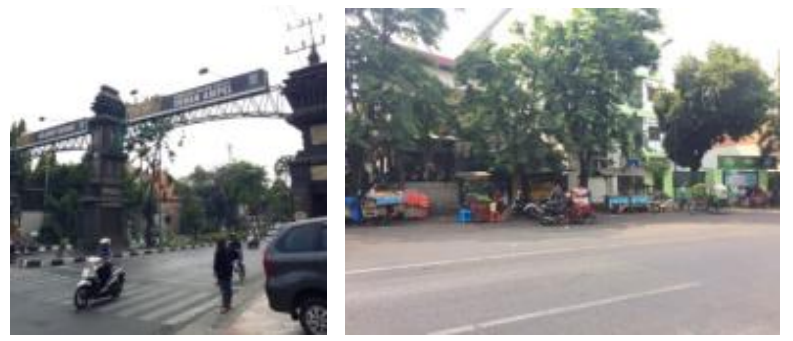

Figure 10. Condition of main road

Source: Personal Documentation

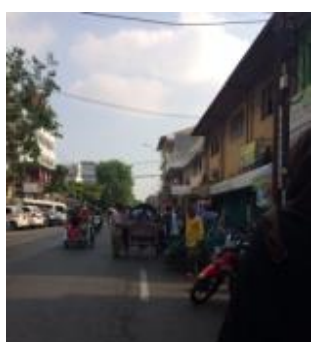

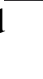

From the observation on road infrastructure, it can be concluded that it needs a roadwork on some streets in the settlements area and main road leading to Ampel Mosque. As suggestion, it should consider the use of pavement materials that meets the concept sustainable.

\title{
- Pedestrian ways
}

The main road in the area of pedestrian ways Ampel has had a stretcher while the road is Jalan Nyemplungan, Jalan Sultan Iskandar Muda, and the KH Mas Mansyur. However, Sultan Iskandar Muda Pedestrian ways is not working as it should be because of the region's pedestrian ways and the roadside used by residents for 
trading activities and parking of vehicles such as cars, motorcycles and tricycles. This forced pedestrians to walk on the street and the main road became narrower. Jalan Nyemplungan is an area with trading functions and services so that the buildings along the road width are shop buildings. In addition, along the way these Nyemplungan pedestrian ways are in use as a patio area and trading parking shop. It causes pedestrians walk on the main road. For pedestrians on the other side of the road is in unfavorable conditions and has potholes. Then on the KH Mas Mansyur pedestrian ways are good enough and used as it should be but do not meet ISO standards due to the lack of some aspects such as the blind paths and green line along the pedestrian. The existing situation can be seen as pedestrian in Figure 11.

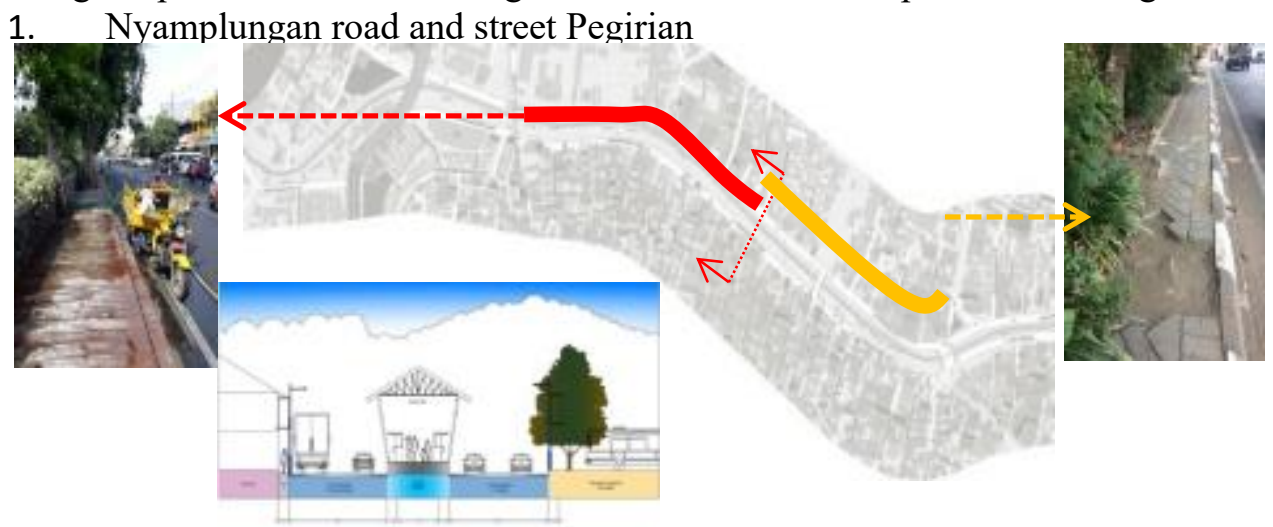

Figure 11.Kondisi Nyamplungan Roads and road Pegirian Source: Personal Documentation

There are two types of pedestrians in Jalan Nyamplungan and Pegirian. The red has a pedestrian using concrete materials whereas on the side of the road segment using yellow colored block-paving material. However, this road has a very poor pedestrian alongside that does not meet the standard of pedestrian city, which at least provides a pathway for the visually impaired pedestrians. In addition, there is still long pedestrian damage and potholes. Reconstruction of pedestrian must meet the requirement of SNI because it is the main route where visitors travel from the parking area to the entrance of the holy Ampel Mosque. The pedestrian in the side of the streets that are directly related to buildings along the road is used as a parking area and street vendors.

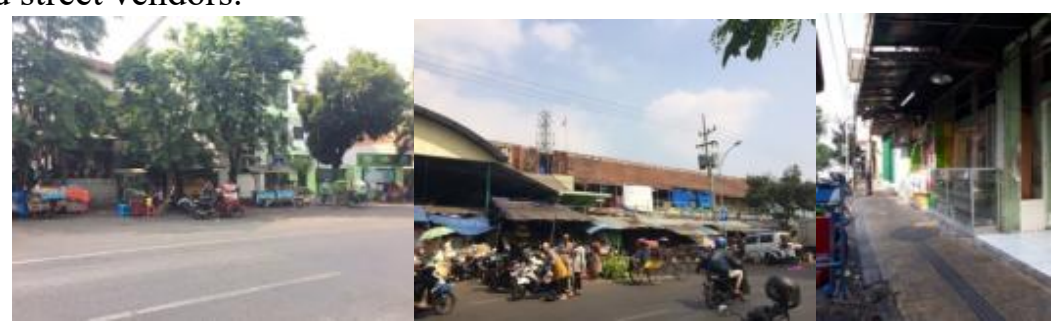

Figure 12. PKL around Jalan Nyamplungan and road Pegirian Source: Personal Documentation 
2. Jalan Sultan Iskandar Muda

Pedestrian ways along Sultan Iskandar Muda has been utilised as its function but needs addition of another track for the blind (Figure 13).

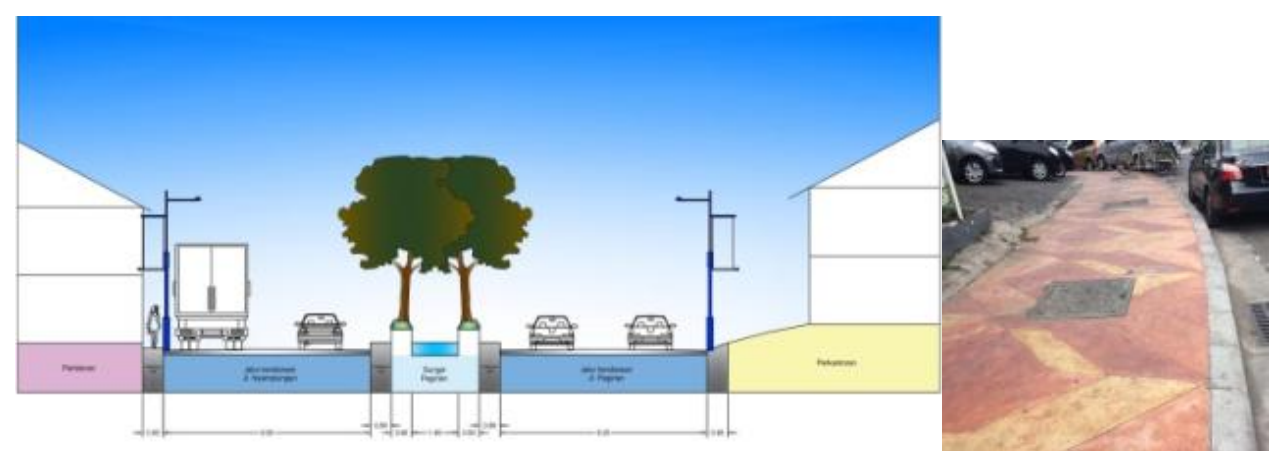

Figure 13. Condition of Pedestrian Jalan Sultan Iskandar Muda Source: Personal Documentation

\section{Jalan KH Mas Mansyur}

In the area of pedestrian Jalan KH Mas Mansyur, PKL, parking and tricycles disturb the pedestrians and activities on the main road because they use most of the road and pavement for activity (Figure 14).

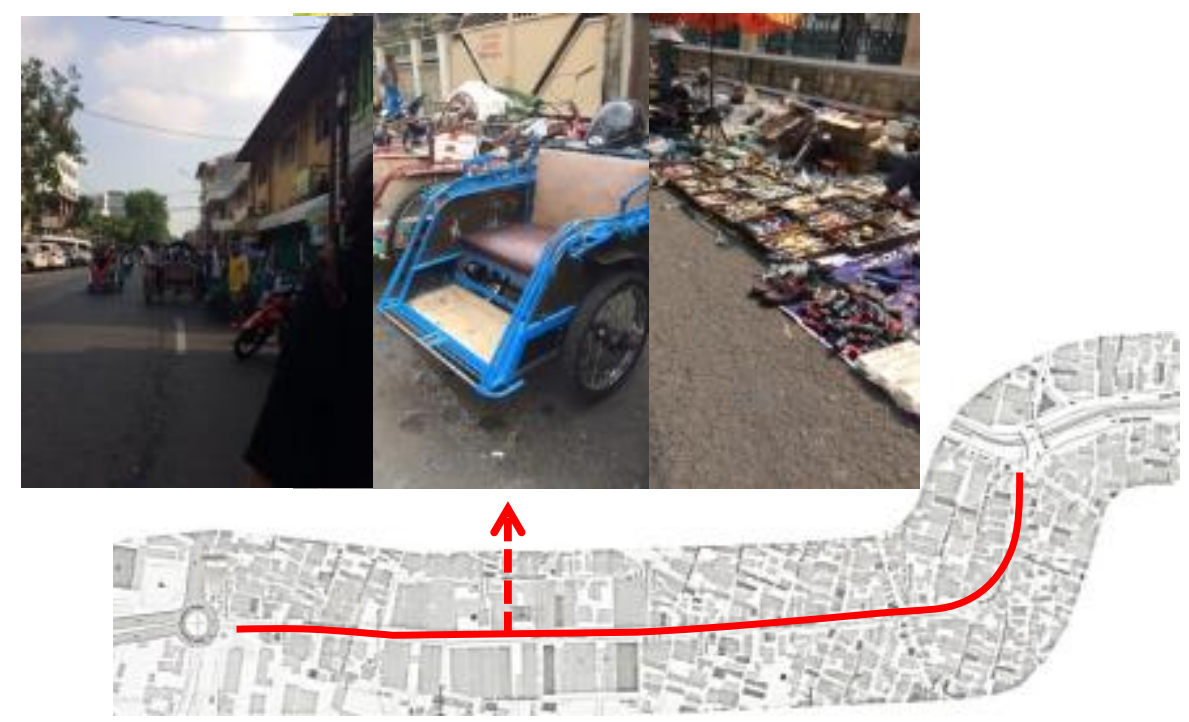

Figure 14. Base rickshaws on the street KH Mas Mansyur Source: Personal Documentation

While on the neighbourhood streets in the residential area (Figure 15), there are no pedestrian ways and it has a road with of $2-3 \mathrm{~m}$ width. Pedestrians should be more careful to not jump into a motor vehicle. And Area backs plan residential areas 
are used by citizens to park their vehicles. Furthermore, the road that has a width of $2 \mathrm{~m}$ is designated for pedestrian. Two-wheel motor vehicles can pass this way but the riders must be very careful.
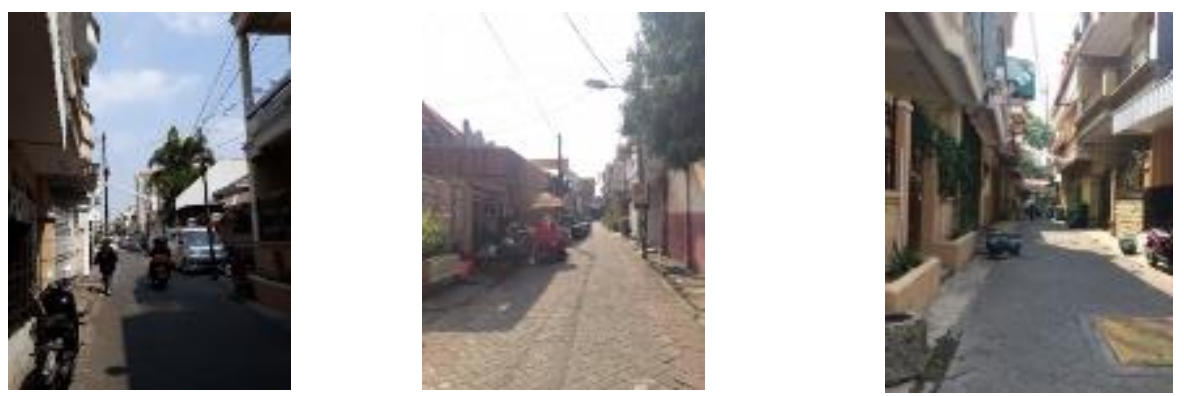

Figure 15 Condition of streets in the neighborhood Ampel region

Source: Personal Documentation

- Sanitation and waste disposal

Sanitation in the sanitary sewer Ampel is closed (Figure 16). Every building in the area of Ampel basic sanitation has been separated from human contact, namely septic tanks, or a toilet that is connected directly to the sewer. Sanitary disposal of household waste in the Ampel area has a system called recharge wells and manholes in every building so that the waste throw out to the city sewers is waste that has been filtered in absorption wells.
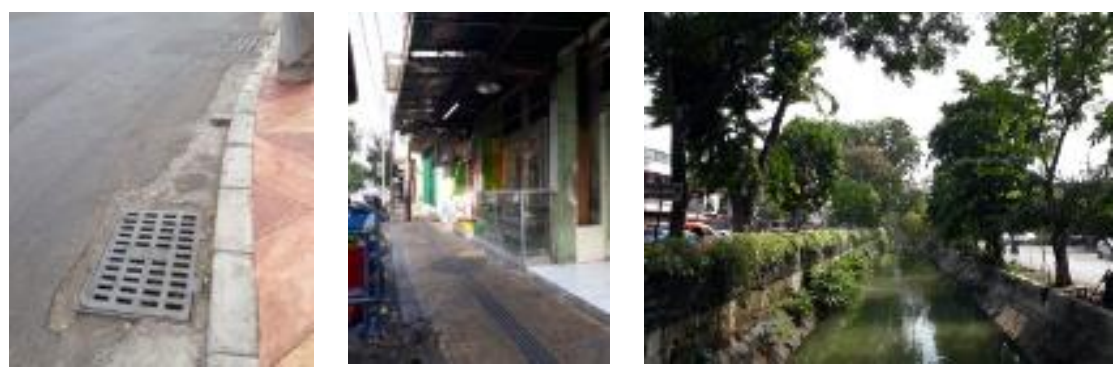

Figure 16.Events sanitation in the Ampel

Source: Personal Documentation

The garbage disposal system in the Ampel region, specifically in residential areas, have been grouped in the Association of cleanliness and garbage services. Each housing provides trash cans and garbage will be transported by a specific officer. In some RT, villagers already provide garbage, which is put on the roadside, and the majority of the community has been very concerned about the garbage. The main street area of government has provided trashcans within a radius of $5 \mathrm{~m}$ with the classification of organic and non-organic trash cans. However, for the trade area, there are still many markets due to the waste bins trading process (Figure 17). 

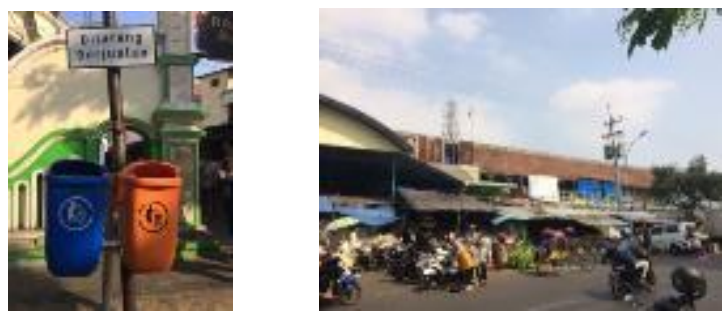

Figure 17. Condition of landfills in the region Ampel

Source: Personal Documentation

- Parking

Ampel region is a religious region where visitors worship Sunan Ampel. Available time to visit the region is 24 hours. However, there are certain days and times in which the area will be filled with visitors such as important religious days and Friday. Visitors come to the end of the outside area with the majority using bus. Therefore, the government provide special parking area for city buses be located in Pergirian road. The location of the parking area is far enough from Ampel Mosque, the main tourist attraction. This is because the 4-wheel vehicles, especially large vehicles, are not allowed to pass through the area. Tourists can not go directly to the mosque. Parking area provided in the courtyard of the mosque is quite limited for motor vehicles and other personal vehicles.

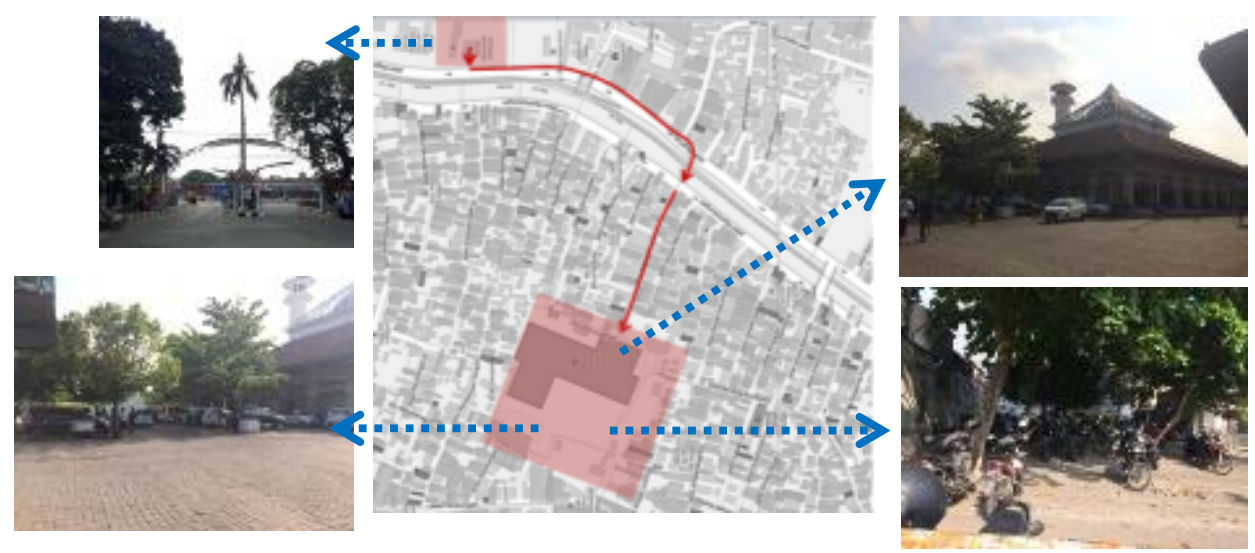

Figure 18, Vehicle parking around Masjid Ampel

Source: Personal Documentation

In addition, the trading and residential area have no or less enough land for parking areas, especially for the road corridor with trading functions. They do not have area to load the dock so that it is commonly found that they load the cargo in the road and disrupts the activities of other drivers and pedestrians. Moreover, the insufficient of parking areas, results in buyers and visitors of the store park their vehicles on the sidewalk and the road (Figure 19). 


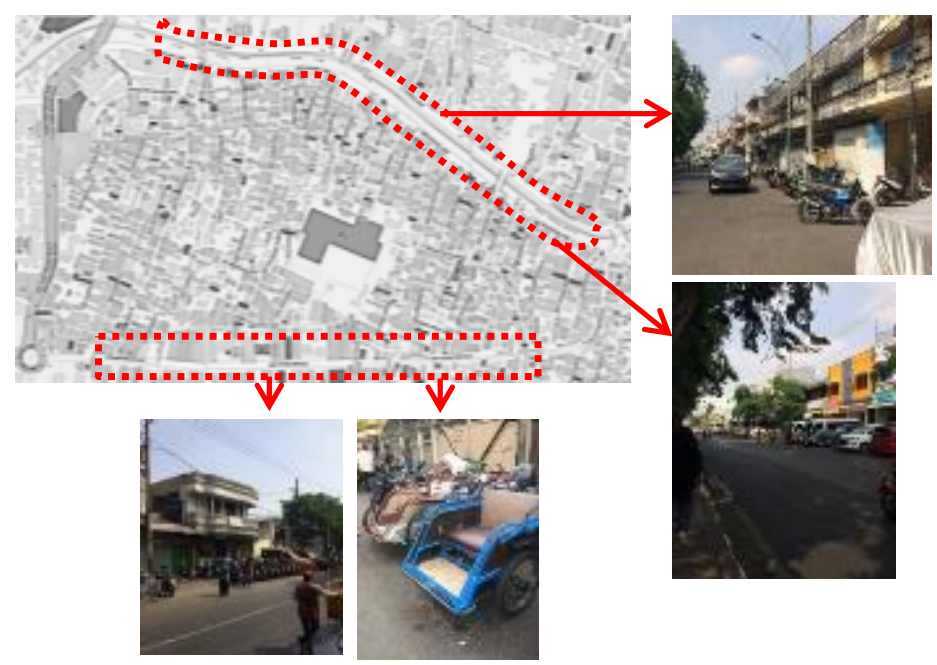

Figure 19. The use of sidewalks and parking on the roadsideto Ampel Mosque Source: Personal Documentation

- Source of water, electricity, telephone/data.

Ampel region is not a slum and from field observations, a network of electricity, water, telephone, and data is available in the area. Futhermore, it is explained as follows: Area Ampel owns source of drinking water. It is the source of drinking water include local water supply pipe, tube container, dug wells, protected springs and rainwater.All lighting fixture in Ampel is powered by the electricity that flows from the main substation. Ampel residential area power system uses a closed network while on the main network along the main road are still using an open network (Figure 20).
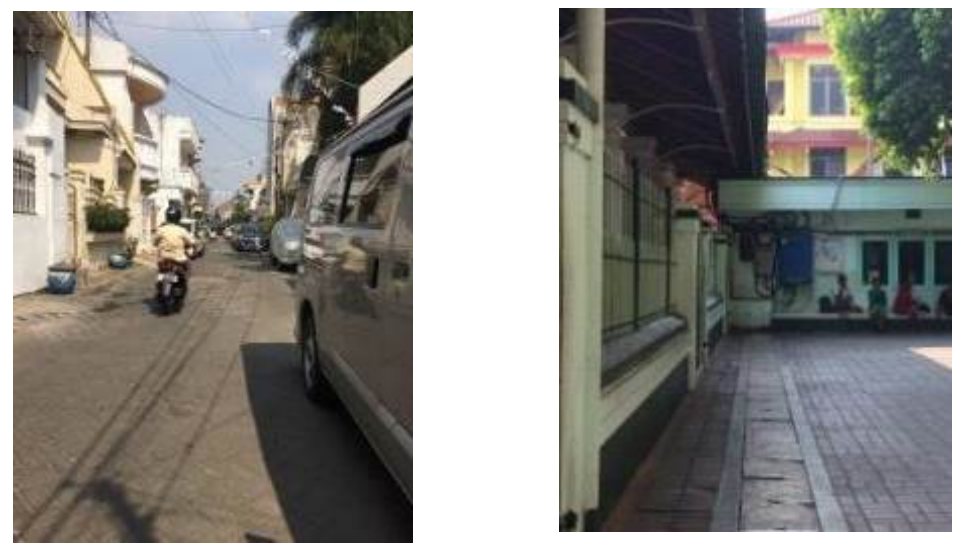

Figure 20. Electric network

Source: Personal Documentation

In Ampel, there is no telecommunication network by telecom and several residents have taken advantage of a mobile data network that has been provided by telecom and other similar companies.

- Green open space 
Ampel region is a highly populated area so that the area of open space is minimal. The only open space available in the region is in the area of Ampel Mosque, which is a sacred conservation heritage pathways (Figure 21). This area is open land that is used as a basis for activities of religious tourism and as an important area of the funeral. The conditions holy Ampel area is not very good. Some facilities, such as toilets and the pedestrian path, is damaged and needs to be fixed. Other facilities such as the break room or sitting for visitors is still lacking. This condition is caused by the lack control of water source facilities, ablution and the lack of hygiene management system caused by tourism activity mainly foreign travelers and non moslem tourists.

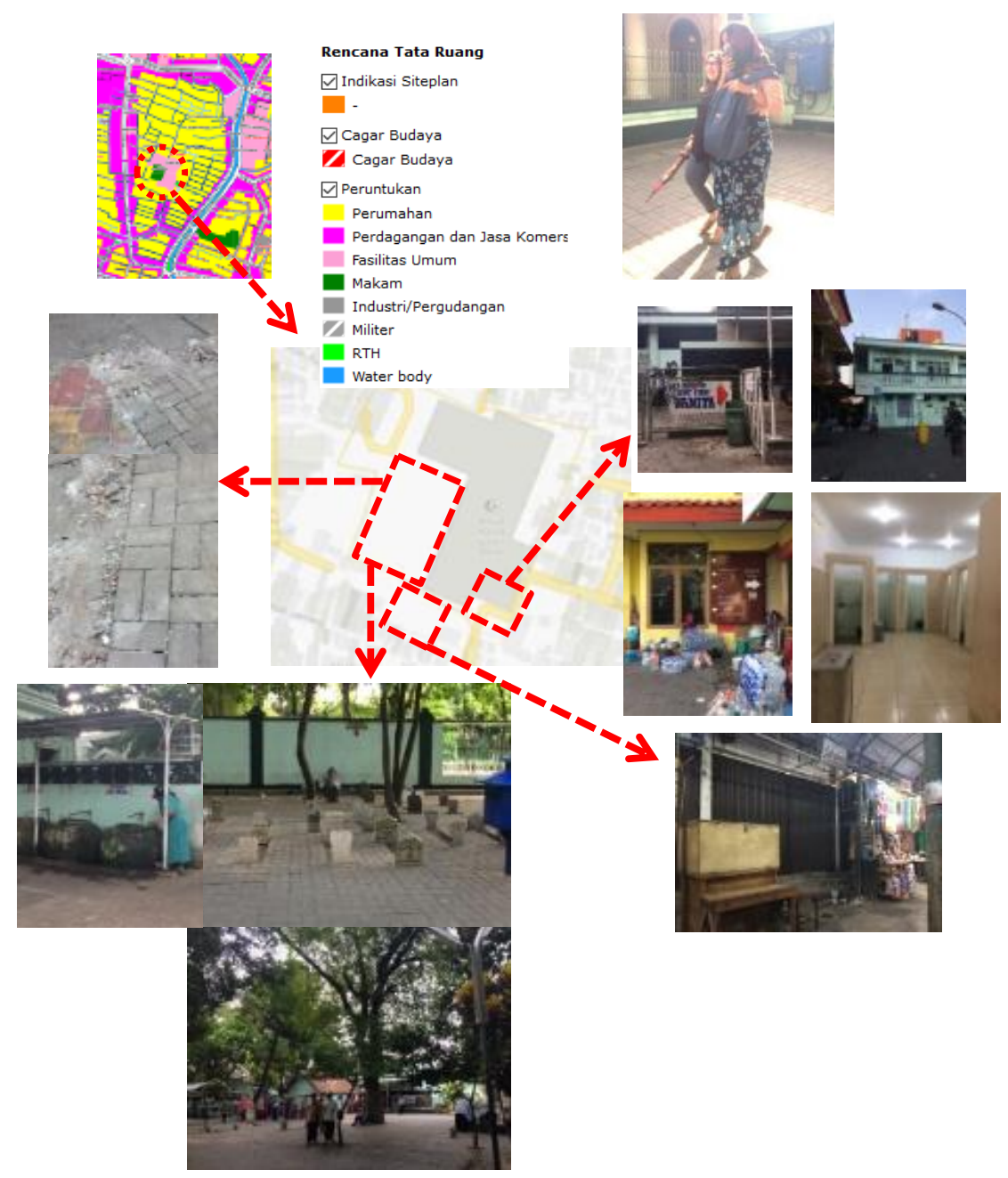

Figure 21. The room open green Ampel Mosque Source: Personal Documentation 


\section{Regional facility}

Ampel region has standard coverage of educational facilities, health, trade, and services (Figure 23). The first is the health care quality, including prevention and treatment, sexual and reproductive health, family planning, routine immunisations and services to basic health. The second is the area of Ampel's pupils facilities. Pupils receive at least one year of early childhood education programs (ECD) qualification and junior high as well as elementary facilities. Thirdly, the economy in Ampel that is an area of trade and services. The main occupation of the resident in this area is merchant and service. In this area, there are many street vendors because it is a religious tourist area. To improve the welfare of the PKL, city government has built and provided a specific area so that the street vendors can be more prosperous. Ampel area is equipped with a security facility belongs to POLSEK Semampir subdistrict. Security in all residential areas in Ampel is provided by the residents. They make portals to cover the entrance to the settlement when at a certain time it is guarded by a security.

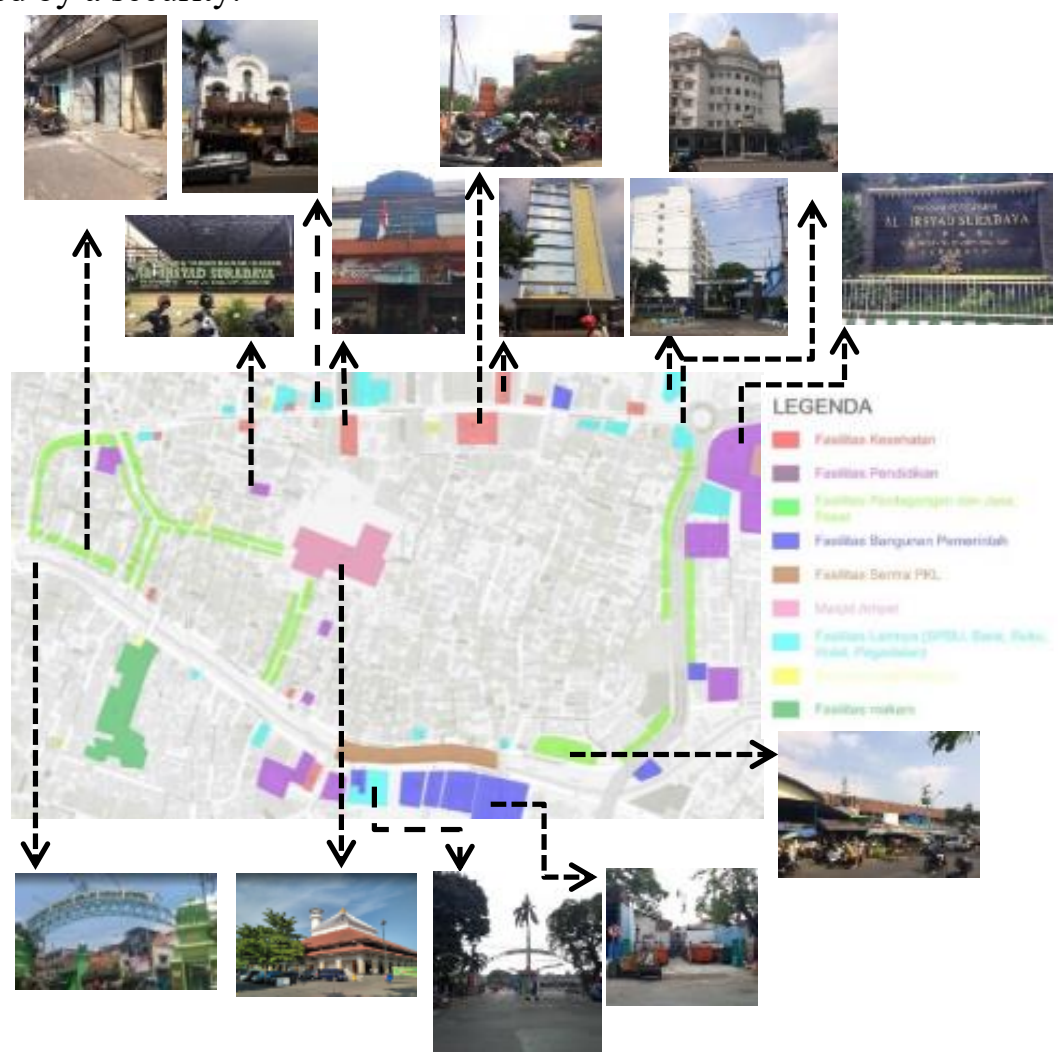

Figure 22.Peta public facilities in the area Ampel Source: Personal Documentation 


\section{Tourist facilities in holy Ampel}

Holy Ampel tourism office and management are located in the area of Ampel Mosque. The function of management is to manage and pay attention to tourism activities in this holy Ampel. However, the board response to the visitors is still very minimum indicated by the lack of services for visitors and lack of traction on the merchant vendors. The facility belongs to the sacred Ampel travel can be seen in Figure 23.

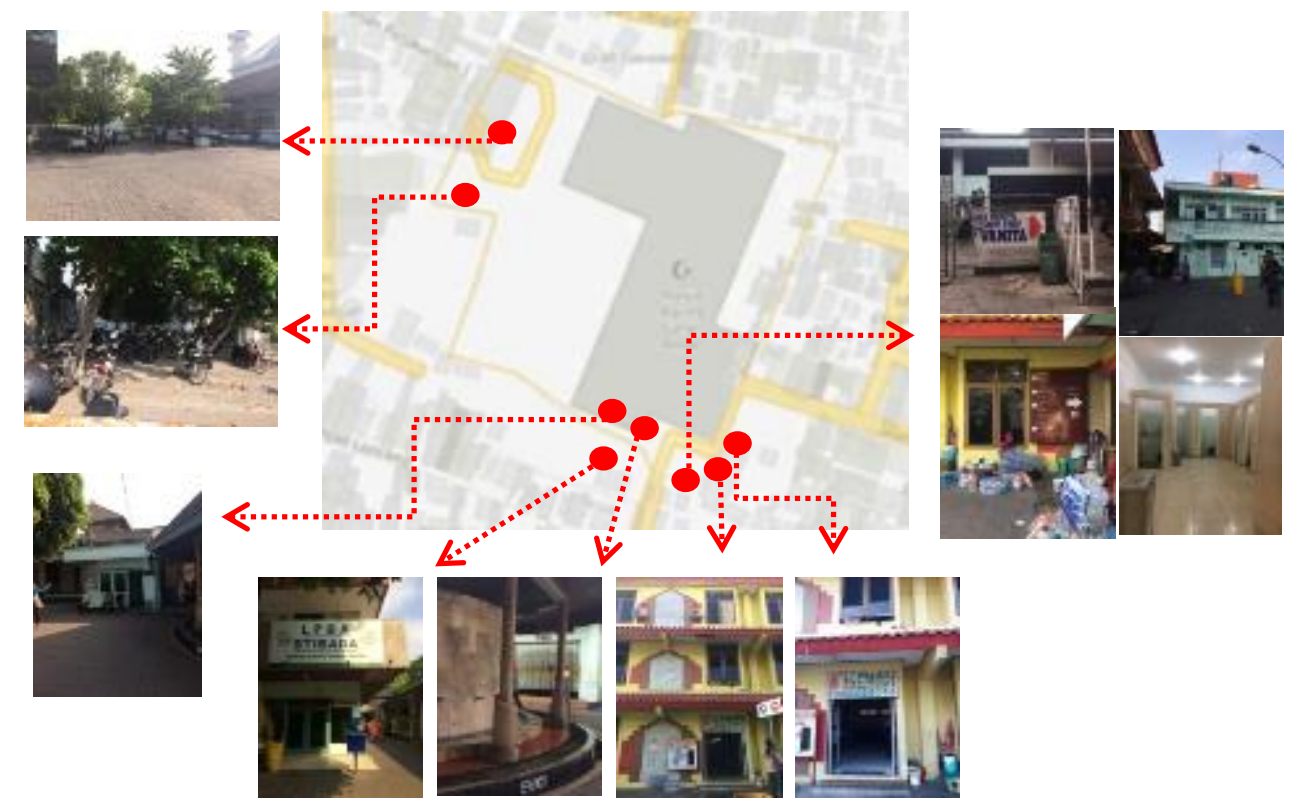

Figure 23.Peta tourist facilities in the area of the holy Ampel Source: Personal Documentation

\section{Preservation Zone}

Ampel region can be developed as one of the urban heritage sites in the city of Surabaya. The number of historical values contained in this village, such as village development history in ancient times as well as the history of the naming of the village, is a valuable asset that must be appreciated. Therefore, this area has the potential to preserve its existence as a historical region, given the region's authenticity, Ampel still well maintained. The diversity of ethnic groups living in this area can be depicted from the combination of European, Chinese, and Arabic architecture that has been existed since the Dutch colonial era. Trading activity is the main support of the lives of most citizens of various ethnic groups in Kampung Ampel. There is a kind of economic stakes in this region and this can lead to interethnic trade competition. In addition, feelings tied to the ethnic group that raises ethnocentrism is something that might happen. Interesting, especially because ethnic groups still survive in every situation, even if there was a conflict. They were able to build Ampel region to became a centre of shopping and religion in Surabaya. 
Roofs are used generally pyramid-shaped, flat roof or shield. The vents are located above or commonly called Dormer gable roof style. While a curvilinear gable roof colonial has jewel with ornaments and a pointed upwards, as shown in (Figure 24). In residential homes, the family of Mr. Isaac appears to consist of acculturation Dutch (curvilinear gable roof models) and Chinese (ornament).
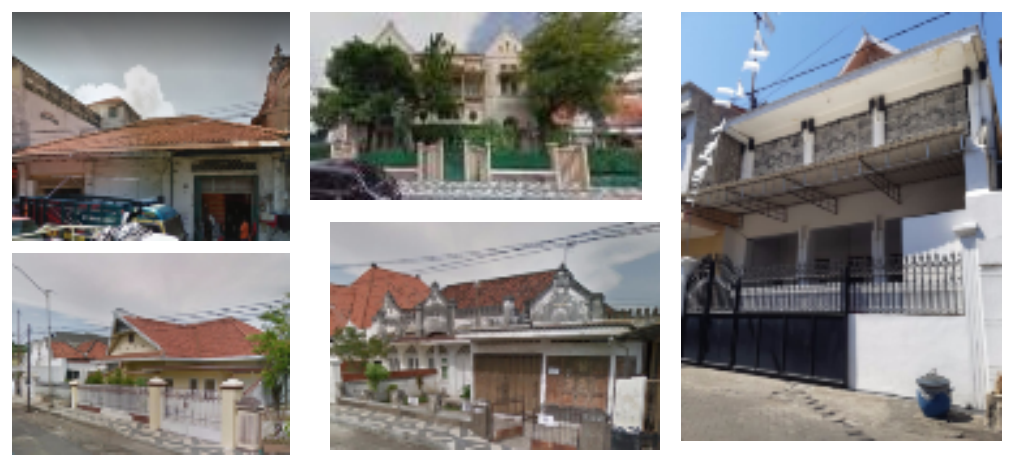

Figure 24, Examples of curvilinear gable style roof house belonging to Sir Isaac Source: personal documentation

Balustrade or guardrail on buildings around the area Ampel can be seen in Balkon. Colours used in this balustrade are vary but generally white or brown and the material used is metal or concrete (Figure 25).
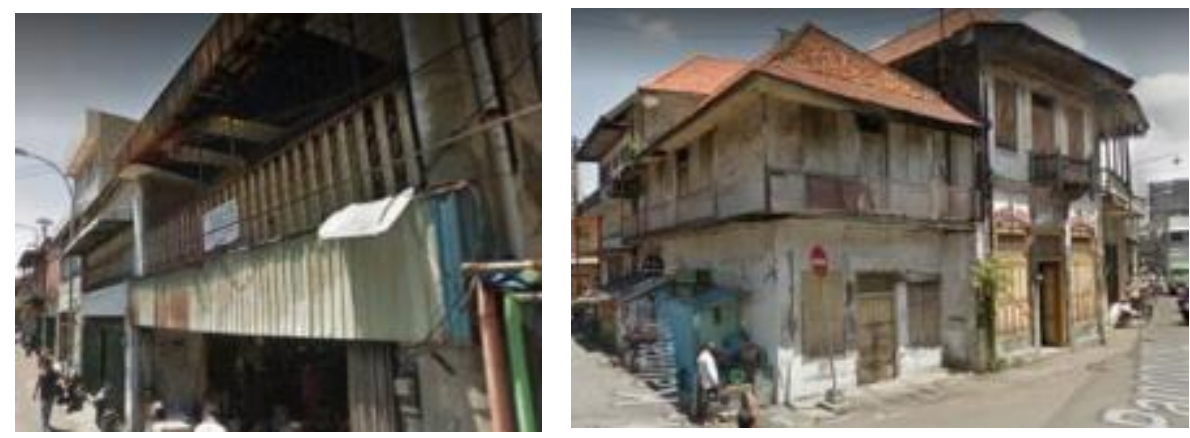

Figure 25. Balustrade installed on the balcony terrace Source: google map

The windows on the building facade have a large size and height; have a strong element of verticality due to the high level with the door window. Glass and wood materials dominate the material window as a whole. Type window blinds window model predominates. This type of window is the hallmark of Indies architecture resulting from the mixing of Western architecture (Netherlands) and Eastern architecture (traditional) are widely applied to the development of the early architecture of the 20th century. The colours used on the window material matching the colour of the door is white material (Figure 26). 

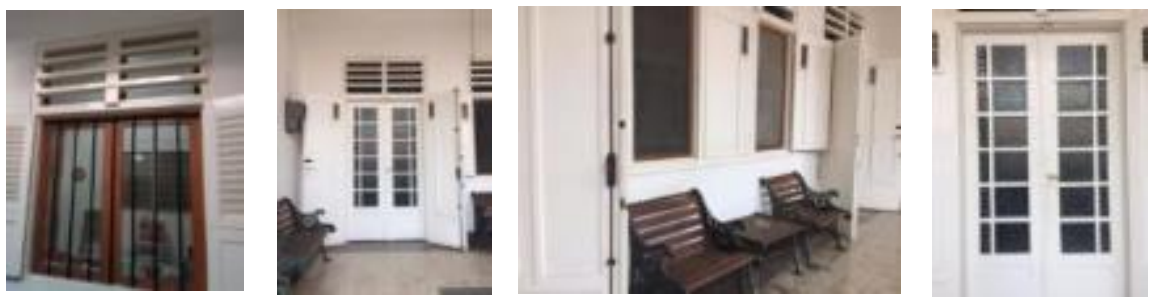

Figure 26. Existing doors and windows of the house of Mr. Isaac

Source: personal documentation

Wall of the overall building uses red brick and plaster. There are two types of wall thickness used to the pristine walls, Dutch colonial heritage is one brick wall \pm $30 \mathrm{~cm}$ while the additional walls or new wall that used to add time and space the new building is a couple of half-brick wall $\pm 15 \mathrm{~cm}$. The colours used for the exterior walls are predominantly white. White domination gives the impression of a monumental. It is one of the characteristic of Indische Empire style buildings with styles that have been developed at that time (Figure 27).
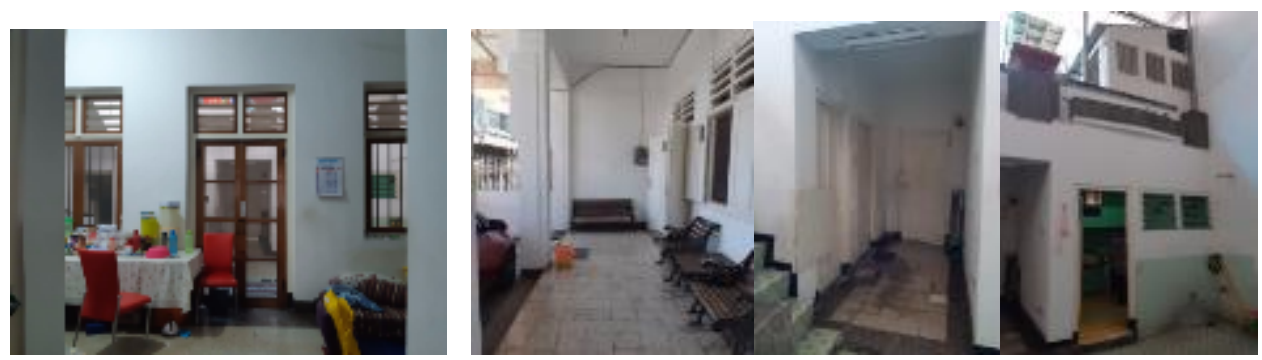

Figure 27, Space in the home of Mr. Ihsak

Source: personal documentation

The floor in one of the houses of Mr. Isaac is biomaterial ceramic with neutral colours like brown, white and yellow tiles size $20 \mathrm{~cm} \times 20 \mathrm{~cm}$. Spaces are composed of a terrace, living room, family room, bedroom, bathroom, kitchen and dining room with linear circulation.

\section{Sunan Ampel Mosque}

Raden Rahmat or Sunan Ampel is a figure that has a high influence in the spread of Islam in East Java. Many students of Sunan Ampel became the leader in Java, namely Sunan Giri, Sunan Bonang and Sunan Drajat. Sunan Ampel mosque was built by Raden Rahmat as a testament to the historical development of Islam in East Java, Java Islamic style.

Colour domination of Sunan Ampel Mosque building elements can be found in Islam. The color composition and color composition of Java, namely:

1. White, means the depiction of the state of man in heaven, according to Islam and the sacred nature in Java;

2. Green, as a symbol of paradise in Islam and as a symbol of peace in Java; 
3. Gold, as a symbol of the greatness of the symbols of Java;

4. Beige / Ivory, as a symbol of happiness in Java (Figure 28).
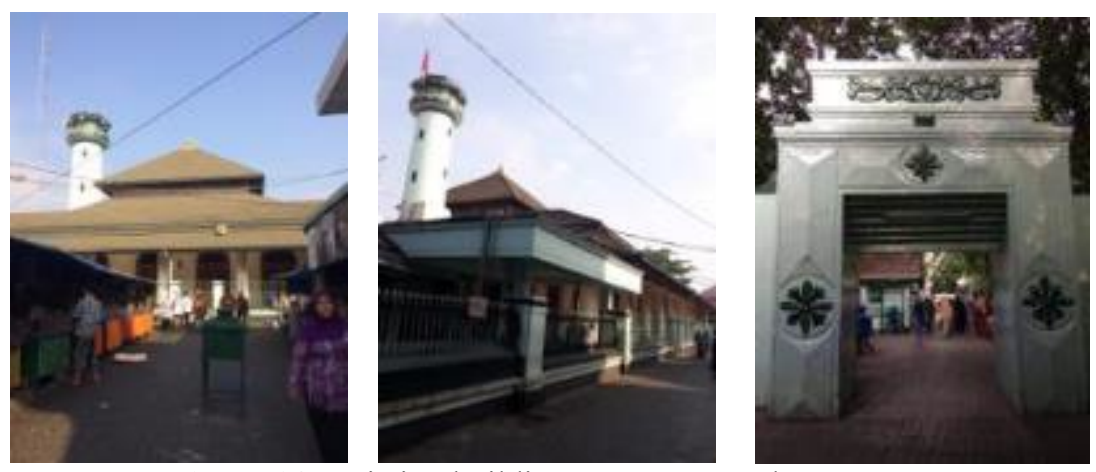

Figure 28, Existing buildings Sunan Ampel Mosque

Source: personal documentation

Ornament the Sunan Ampel Mosque building element is a combination of Islamic and Javanese ornaments. Java ornaments is found on the gate with a symbol of fertility (Figure 30) and solar stylization Wilwatikta. In ornaments on the rostrum, there is vine as a symbol of beauty, and solar Wilwatikta makutha as well as a symbol of purity. Ornaments on the roof of the old Mosque and Gates leading to the tomb use Makutha as a symbol of purity.

Dark is the sanctity parameters of Masjid Wali Songo in ancient times. The concept of the dark with a combination of bright light as an element of the primacy of a concept is reflected in the modernisation sacred mosque. The concept of dark light on the old mosque by the light-dark concept as found formerly in Masjid Wali Songo is illustrated by no opening in the roof and little of light because it is adjacent to the foyer (Figure 31). Sacred expression of the past was created by a dark room and at least a light coming into the room.

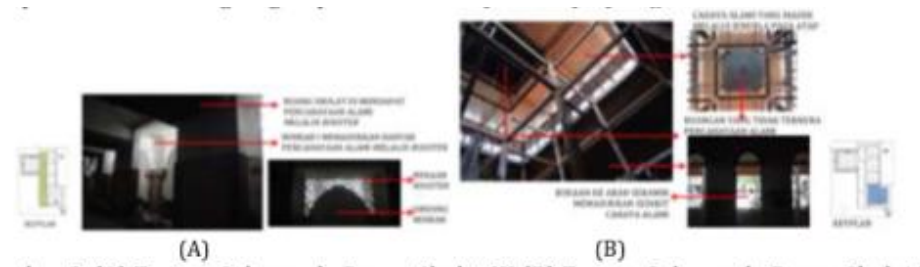

Gambar 3. (A) Terang Gelap pada Ruang Sholat III (B) Terang Gelap pada Ruang Sholat I

Figure 29, Bright Dark On Prayer Room

Source: personal documentation

Orientation of the building is based on the position of the Mosque with the grave does not indicate the level of importance of the Mosque tombs for their expansion in the Northside of the tomb. The orientation of the building is currently attending the orientation of the Mihrab in the Old Mosque. 


\section{Socio-economic}

Providing the social interaction space with attention to the economic characteristics, Sunan Ampel tomb area is one of the trade areas in Surabaya. There are variety of stores, ranging from building stores, clothing stores, food stalls, to store food such as bread typical middle east Mariam and dates can be found in Ampel. Ampel neighbourhood encounter in religious tourism has been renowned throughout the country, namely religious tourism Sunan Ampel. At this location, there is the tomb of Sunan Ampel and the Sunan Ampel Mosque. The density of the number of pilgrims who visited the tomb of Sunan Ampel makes traders open business around the region.

Along the corridor area of Jalan KH Mas Mansyur, ubiquitous street vendors cover half of the street. Goods are sold mostly secondhand household items and accessories such as agate. Although there are signage to ban selling along the corridor, they tend to break the rules. This makes the traffic congest and the number of vehicles parking haphazardly. The city administration has to make a solution that builds central street vendors located in the middle. But it was considered a failure because they did not want to move with reason of reduced selling after they are moved.

For that, we need no further action to solve the chaotic street vendors trading solutions. Their problems are on the mentality and the way of life. They are a bit much-contaminated by the street culture. It can be reduced by providing socialisation such as educating the importance of road space utilisation with the previous function as a vehicle. For the seller itself, they can use the lane street. It is hoped that the traders were willing to occupy the space that has been provided (Figure 30)
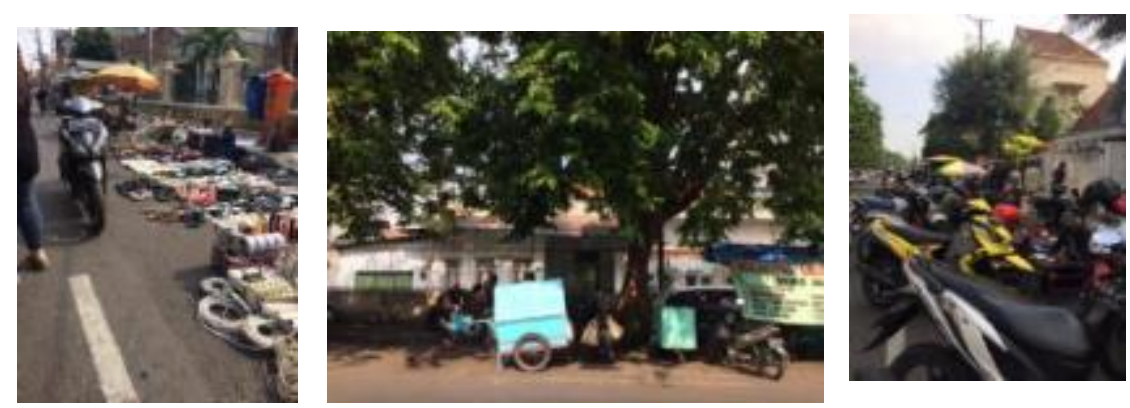

Figure 30. Views hawkers and parking is not in place Source: personal documentation

Other social-economic activities are often held in the annual bazaar. Activities are held by residents of surrounding residential. There is no problem found because they carry out their activities from their homes by opening a kiosk on the home yard (Figure 31) 


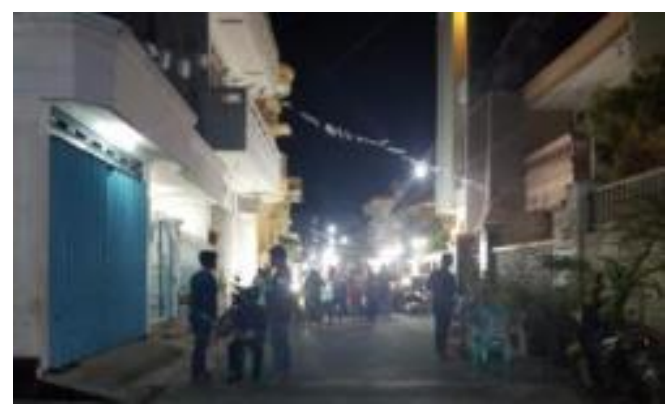

Figure 31. Views Bazar village

Source: personal documentation

- environmental security,

On a micro-scale, it is partly encountered by a barrier of fences in every alley entrance residential areas around Masjid Sunan Ampel (Figure 34). It is as a signage alleyway territory that enters the area are limited by time. In addition, the locals in the area have a very high concern to one another. For example, when there is a stranger who enters his or her alley, and then the guest will be asked personally about their interests and will visit the home to anyone to maintain the security of occupancy. While the macro scale, there is a police station located in the District Semampir Pegirian.
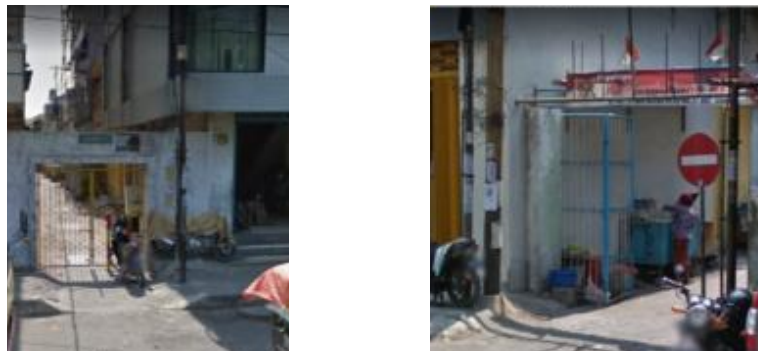

Figure 32, Guardrail in every aisle residential neighborhood Ampel Source: Google map

- $\quad$ preserving the environment,

Based on survey results, the implementation of environmental preservation is considered to be good. It is indicated by providing trash basket in every point and every point of entry corridor residential alley. The janitor who regularly sweep the area transports the waste to be distributed to nearby landfills located in Pegirian (Figure 33). It is also found several watering cars provided by central government comes every morning. But unfortunately, the density of the population in the area is too high. It makes the lacking space for green open spaces. It is suggested to provide socialisation for planting greenery in every home and implement it based on the voluntary work of citizens regularly. It helps to create a healthy environment and a comfortable dwelling. 


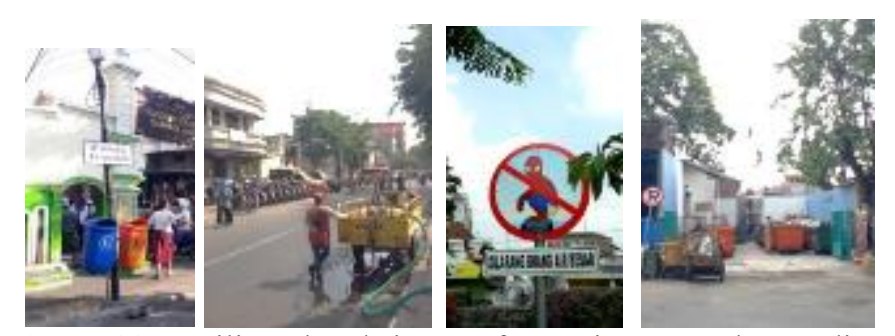

Figure 33. Facilitated and signage for environmental custodians

Source: personal documentation

\section{CONCLUSIONS}

From the analysis, it can be concluded that several aspects should be improved in the tourist area to meet the convenience of the public and tourist visitors for Ampel development. The results of the analysis can be seen as follows in Table 3.

Table 3. Results of analysis

\begin{tabular}{|c|c|c|c|}
\hline & Element analysis & Fix / no & Results of analysis \\
\hline & $\begin{array}{l}\text { Land use } \\
\text { (Land Use). }\end{array}$ & No & $\begin{array}{l}\text { Ampel owns allotment of land area by } \\
\text { the function of the area that is those areas } \\
\text { of cultural heritage. }\end{array}$ \\
\hline & $\begin{array}{l}\text { Landuse (Building Form } \\
\text { and Massing) }\end{array}$ & No & $\begin{array}{l}\text { Based on several considerations, the } \\
\text { coefficient floor of the building, the basic } \\
\text { building coefficient, and the lines on the } \\
\text { building sempadan Ampel Region have } \\
\text { been specifically set by the government and } \\
\text { should be applied at the time of rebuilding. }\end{array}$ \\
\hline 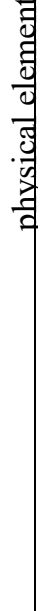 & $\begin{array}{l}\text { infrastructure including } \\
\text { Circulation and parking } \\
\text { (Circulation and Parking) }\end{array}$ & repair & $\begin{array}{l}\text { - Circulation: do some repair to the } \\
\text { damaged roads and cover potholes, use } \\
\text { paving materials that meet the } \\
\text { sustainable standard such as paving } \\
\text { blocks to maximise the seepage of rain } \\
\text { and facilitate the repair of roads. } \\
\text { Pedestrian ways: repair pedestrian } \\
\text { ways on the main roads such as roads } \\
\text { Nyamplungan and Pegirian road. } \\
\text { - Sanitation and waste disposal: } \\
\text { environment sanitation system in a } \\
\text { closed channel has been very good. It } \\
\text { leads to environmental sanitation which } \\
\text { has been through filtration wells in } \\
\text { every home. }\end{array}$ \\
\hline
\end{tabular}




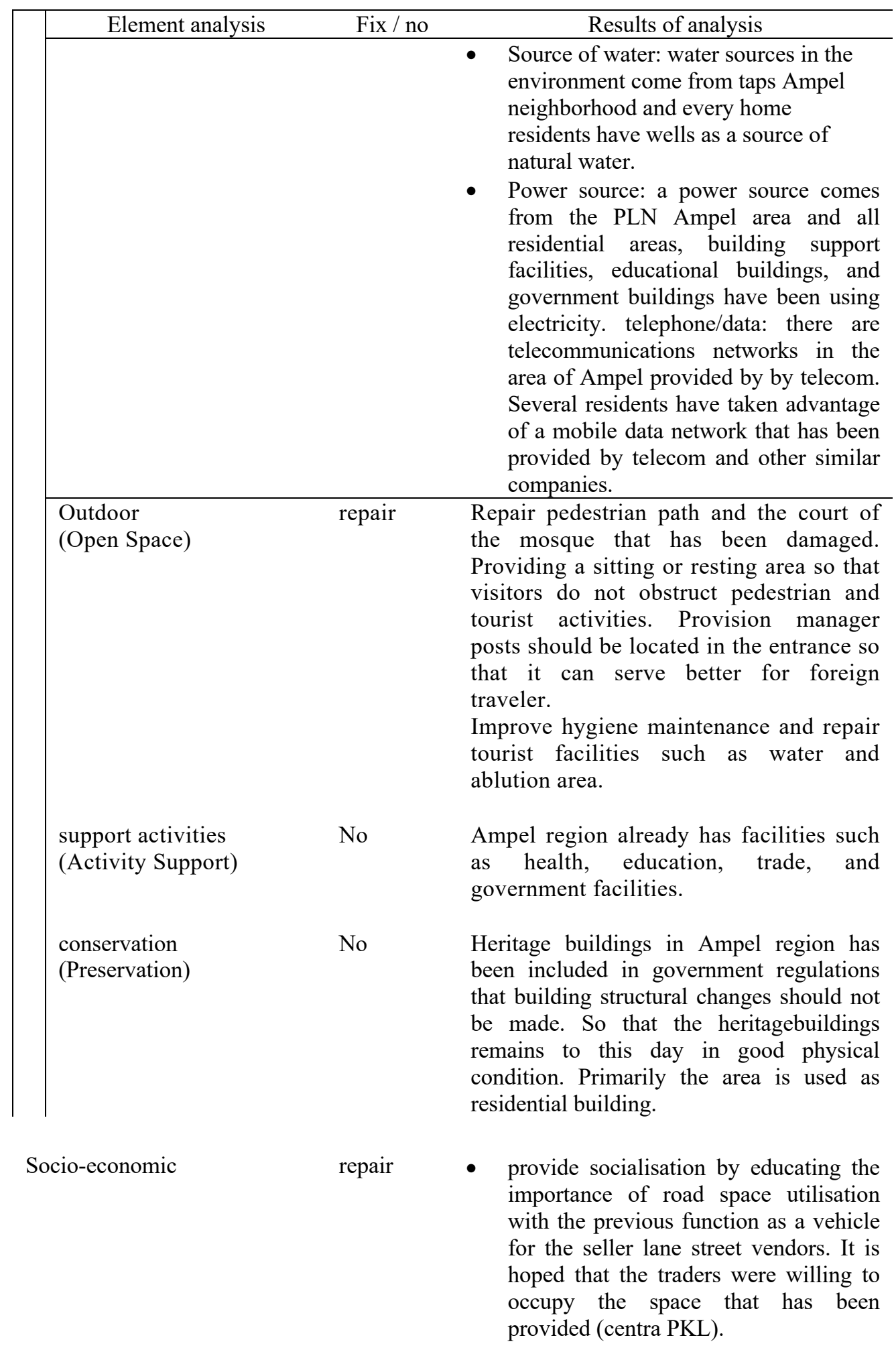




\begin{tabular}{lll}
\hline Element analysis & Fix / no & \multicolumn{1}{c}{ Results of analysis } \\
\hline & & $\begin{array}{l}\text { Suggest a sosialisation for planting } \\
\text { greenery in every home based on voluntary } \\
\text { work from the citizens regularly. It helps to } \\
\text { create a healthy environment and a } \\
\text { comfortable dwelling. }\end{array}$ \\
\hline Sustainable & repair & $\begin{array}{l}\text { Repair in every physical aspect of the } \\
\text { region should pay attention to the concept } \\
\text { of sustainable architecture. }\end{array}$ \\
\hline
\end{tabular}

\section{Recommendations of design}

Bsed on the previous analysis, Ampel design recommendations with the implementation of a sustainable region following the points are described as follows:

\section{Infrastructure}

Recommendations for infrastructure is improving circulation and pedestrian ways are described as follows:

- Circulation:

Improve circulation in residential area that was damaged by the application of block paving material (Figure 34)

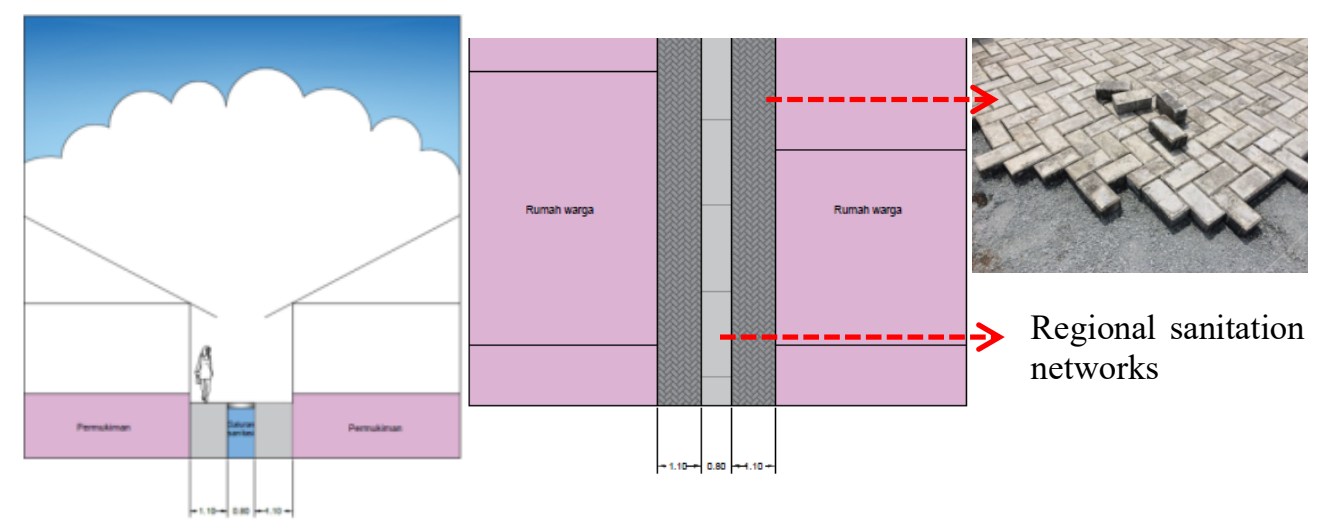

Figure 34. Network of sanitation department

Source: personal design

- Pedestrian ways:

Pedestrian improvements on the main road:

* Nyemplungan road and Pegirian (Figure 35 and 36) 


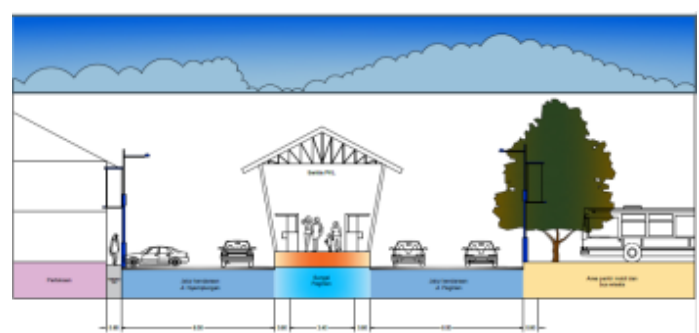

Figure 35 . Condition of JalanPenyemplungan and pergirian Source: personal design

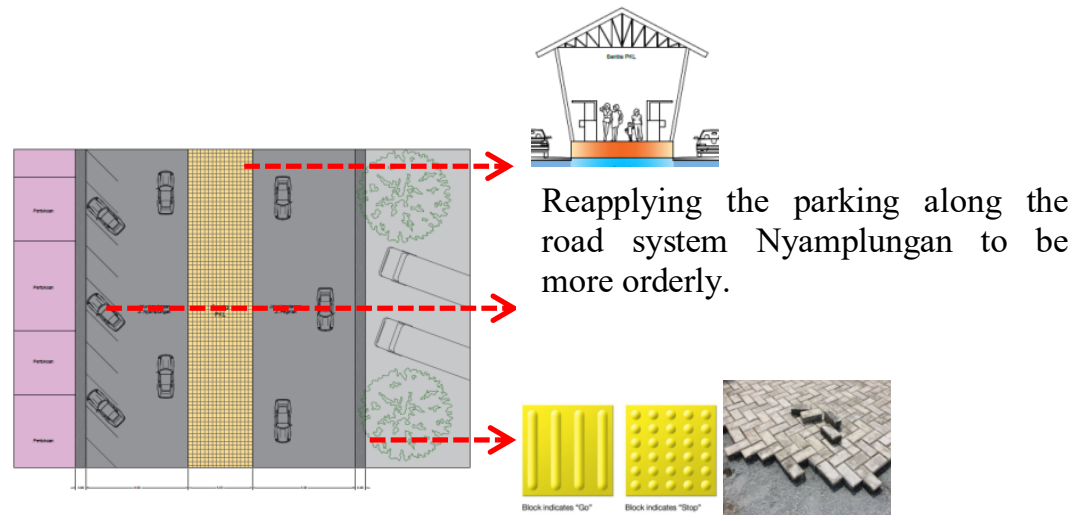

Figure 36 . Recomendation for Nyamplungan and Pegirian

Source: personal design

Uphold the regulations strictly for activities out of the goods and the large truck trade area, especially in the hours with the activities of the low road.

\section{* Jalan KH Mas Mansyur}

Evict street vendors along the road corridor KH Mas Mansyur so that the corridor can be used by motor vehicle to the maximum (Figure 37 and 38)

Existing Recommendatio

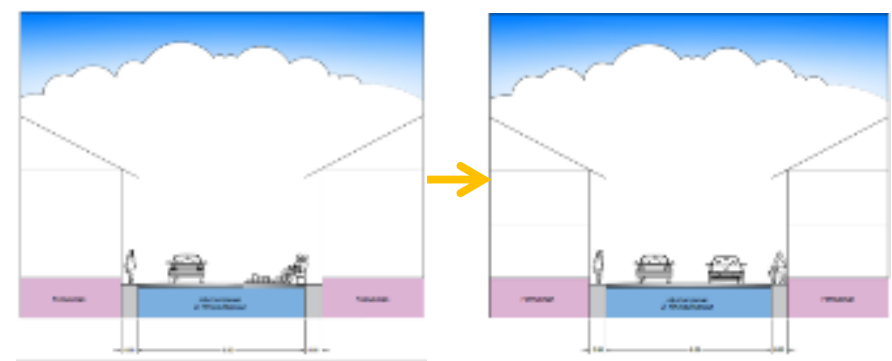

Figure 37 . Contion of Penyemplungan and Pergirian Source: personal design 

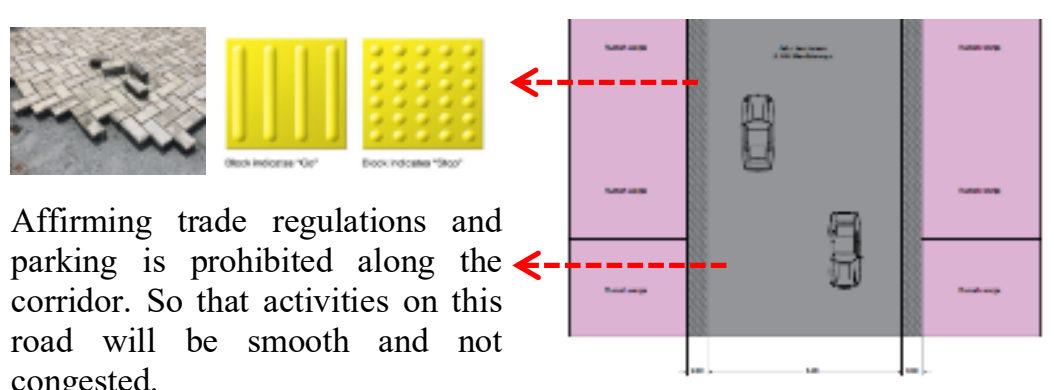

Affirming trade regulations and parking is prohibited along the corridor. So that activities on this road will be smooth and not congested.

Figure 38. Existing and Recommendations for Jalan Nyamplungan

Source: personal design

\section{Open space (Open Space)}

- Improve pedestrian and the court of the Mosque that has been damaged by using environmentally friendly pavement namely paving blocks. Therefore, it can absorb water well when it rains and reduce the impact of flooding.

- Provide a seating area or breaks, so the visitors do not obstruct pedestrian and tourist activities.

- Locate the provision manager posts at the entrance and exit of foreign traveler, so it can serve better and more pathways can be developed; Improve hygiene maintenance and repair tourist facilities such as water and ablution area.

\section{Socio-economic}

Recommendations in the form of efforts to combat trafficking, street vendors who are stubborn

- Deploy 30 joint personnel from the police, Satpol PP and Koramil. Each must consist of respectively 10 participants for raids. Provide preventive legal action/prevention (oral and written guidance) and the repressive / law enforcement (the act of investigation by the police).

- Design the Shelter and provide skills-building such as gardening, cooking, sewing, and crafts.

- Carry out the selection based on population data, whether they are from the local area or from outside the region

- Make the Need guidance in social and education by providing facilities for the Department of Social Development Ampel and the surrounding area. This should be supported by government funding to facilitate.

\section{REFERENCES}

Book:

Jacobs, Jane. (1961), The Death and Life of Great American Cities, Vintage Books, New York. 
Shirvani, Hamid. (1985), The Urban Design Process, Van Nostrand Reinhold Company, New York.

Tibbalds, Francis. (1992), Making People-Friendly Towns: Improving the Public Environment in Towns and Cities, Longman Group Ltd., London.

\section{Journal:}

Abadi, AA (2011), Towards Eco-Urban Settlement: Learning from Low-Mid Housing Vacancy Phenomena in The City of Bekasi, Architecture \& Environment, 10 (2), 137-148, School of Architecture, Planning and Policy Development, Institute of Technology Bandung, Indonesia.

Herliana, ET (2017), Exploring a Sense of Place for the Sustainability of Heritage District in Yogyakarta, Architecture \& Environment, 16 (2), 75-92, Department of Architecture, Faculty of Architecture, Design, and Planning, Institute of Technology, Indonesia.

Krisdianto, John. (2011), The Concept Of Housing With Bioclimatic Architecture Approach That Considers Human Perspective To Obtain A Better Settlement And Energy Conservation, Architecture \& Environment, 10 (2), 165-170, Department of Architecture, Faculty of Architecture, Design, and Planning, Institute of Technology, Indonesia.

Letfiani, Widyasari. (2015), Kampung Maspati as a Sustainable Village in Surabaya City, Architecture \& Environment, 14 (2), 163-172, Department of Architecture, Faculty of Architecture, Design, and Planning, Institute of Technology, Indonesia.

Mayasari, feti. (2012), The Development of the Arab village as a Tourism Village in Surabaya, Architecture \& Environment, 11 (2), 127-138, Department of Architecture Institute of Technology, Indonesia.

Rahmadaniyati, Kisnarini, Septanti. (2016), The Arrangement Concepts for Environmentally Sustainable Housing Land Efficiency, Architecture \& Environment, 15 (1), 41-52, Department of Architecture, Faculty of Architecture, Design, and Planning, Institute of Technology, Indonesia.

Toofan, Sahar. (2014), Importance of Human Design for Sustainable Landscape. IACSIT International Journal of Engineering and Technology, 6 (6), December 2014

Akadiri PO, Chinyio EA, Olomolaiye PO, (2012), Design of Sustainable Building: A Conceptual Framework for Implementing Sustainability in the Building Sector, Buildings, 2012, from 2.126 to 152; DOI: $10.3390 \%$ buildings2020126, 4 May 2012, United Kingdom 
Fajarwati, Sari, Ishak. AMPEL HERITAGE TOURISM AREA IN THE CONTEXT OF SUSTAINABILITY

This Page is Intentionally Left Blank 